\title{
Model-Based Analysis of an Integrated Zinc-Air Flow Battery/Zinc Electrolyzer System
}

\begin{abstract}
Woranunt Lao-atiman ${ }^{1}$, Kanya Bumroongsil ${ }^{1}$, Amornchai Arpornwichanop ${ }^{1,2}$, Palang Bumroongsakulsawat ${ }^{1}$, Sorin Olaru ${ }^{3}$ and Soorathep Kheawhom ${ }^{1,2 *}$
\end{abstract}

${ }^{1}$ Department of Chemical Engineering, Faculty of Engineering, Chulalongkorn University, Bangkok, Thailand, ${ }^{2}$ Computational Process Engineering Research Unit, Chulalongkorn University, Bangkok, Thailand, ${ }^{3}$ Laboratory of Signals and Systems,

CentraleSupélec, Université Paris-Saclay, Gif-sur-Yvette, France

This work aims at analyzing an integrated system of a zinc-air flow battery with a zinc electrolyzer for energy storage application. For efficient utilization of inherently intermittent renewable energy sources, safe and cost-effective energy storage systems are required. A zinc-air flow battery integrated with a zinc electrolyzer shows great promise as an electricity storage system due to its high specific energy density at low
OPEN ACCESS

Edited by:

Hua Kun Liu,

University of Wollongong, Australia

Reviewed by:

Liqiang Mai,

Wuhan University of Technology,

China

School of Materials \& Mineral Resources Engineering, University of

Science, Malaysia

*Correspondence:

Soorathep Kheawhom soorathep.k@chula.ac.th

Specialty section:

This article was submitted to Electrochemical Energy Conversion and Storage,

a section of the journal Frontiers in Energy Research

Received: 17 November 2018 Accepted: 05 February 2019

Published: 22 February 2019

Citation:

Lao-atiman W, Bumroongsil $K$, Arpornwichanop A, Bumroongsakulsawat $P$, Olaru $S$ and Kheawhom S (2019) Model-Based Analysis of an Integrated Zinc-Air Flow

Battery/Zinc Electrolyzer System.

Front. Energy Res. 7:15.

doi: 10.3389/fenrg.2019.00015
Ahmad Azmin Mohamad, cost. A mathematical model of the system was developed. The model was implemented in MATLAB and validated against experimental results. The validation of the model was verified by the agreement between the simulation and experimental polarization characteristic. The behavior and performance of the system were then examined as a function of different operating parameters: the flow rate of the electrolyte, the initial concentration of potassium hydroxide $(\mathrm{KOH})$ and the initial concentration of zincate ion. These parameters significantly affected the performance of the system. The influence of the hydrogen evolution reaction (HER) on the performance of the system was investigated and discussed as it significantly affected the coulombic efficiencies of both the zinc-air flow battery and the zinc electrolyzer. Optimal $\mathrm{KOH}$ concentration was found to be about 6-7 M. Whilst increased $\mathrm{KOH}$ concentration enhanced the discharge energy of the battery, it also increased HER of both the battery and the electrolyzer. However, higher initial concentration of zincate ion reduced HER and improved the coulombic efficiency of the system. Besides, a higher flow rate of electrolyte enhanced the performance of the system especially at a high charge/discharge current by maintaining the concentration of active species in the cell. Nevertheless, the battery suffered from a higher rate of HER at a high flow rate. It was noted that the model-based analysis provided better insight into the behavioral characteristics of the system leading to an improved design and operation of the integrated system of zinc-air flow battery with the zinc electrolyzer.

Keywords: zinc-air battery, zinc electrolyzer, simulation, energy storage, flow battery

\section{INTRODUCTION}

Nowadays, renewable energy has captured the public interest and has been extensively explored due to the increment in energy demand and stringent climate change targets (Li and Dai, 2014; Jing et al., 2017). Renewable energy sources, therefore, such as solar and wind have a strong potential to fulfill the need. Nevertheless, their practical employment has been limited by their variability and 
intermittent nature. Thus, a reliable and cost-effective energy storage system (ESS) is required for efficient utilization of renewable energy sources (Zhang, 2013). Besides, ESS can play a significant role to enhance stability and flexibility of a power grid in both supply and demand (Dunn et al., 2011).

Zinc-air batteries are a promising ESS because of their high practical specific energy, up to $700 \mathrm{Wh} / \mathrm{kg}$ (Li et al., 2013). Zinc $(\mathrm{Zn})$ is also an attractive anodic active material because it is non-toxic, safe, abundant and low-cost (Lao-atiman et al., 2017). Besides, $\mathrm{Zn}$ exhibits high stability and reversibility during charge-discharge cycle (Zhu et al., 2016). Zn-air batteries generate electricity through the electrochemical reaction of $\mathrm{Zn}$ and oxygen. During discharge of the battery, $\mathrm{Zn}$ anode is oxidized and produces zincate and later changes to zinc oxide whilst, at the cathode, oxygen from the atmosphere undergoes reduction. As the cathodic active material is not enclosed in the cell, $\mathrm{Zn}$ air batteries exhibit very high energy density. Zn-air batteries have been fabricated in various forms and shapes, such as flexible batteries (Fu et al., 2016; Suren and Kheawhom, 2016; Wang et al., 2017), cable-type batteries (Park et al., 2015), and flow batteries (Bockelmann et al., 2016; Hosseini et al., 2018; Wang et al., 2018). Flow batteries have a wide power range and much higher capacity ratings. In addition, they can independently scale the power and capacity by storing active materials outside the cell. In other words, flow batteries allow for independent scale-up of power and capacity specifications (Escalante Soberanis et al., 2018). Thus, regarding cost, system flexibility, quick response and safety concerns for large-scale applications, flow batteries exhibit significant advantages over other types of battery.

$\mathrm{Zn}$-air batteries can be recharged by two approaches: electrical recharge and mechanical recharge (Xu et al., 2015; Mainar et al., 2018). An electrically rechargeable $\mathrm{Zn}$-air battery is recharged by supplying electricity directly to the cell. During recharge, oxygen is generated at the air electrode whilst $\mathrm{Zn}$ metal is electrochemically regenerated at the $\mathrm{Zn}$ electrode. A significant problem of the $\mathrm{Zn}$ electrode is the formation of dendritic $\mathrm{Zn}$ during recharge. Moreover, during recharge, the air electrode rapidly deteriorates due to the growth of oxygen bubbles and the air electrode corrosion (Pei et al., 2014). These issues are a critical life cycle-limiting factor for rechargeable $\mathrm{Zn}$-air batteries. These problems can be avoided by using a mechanical recharging approach. A mechanically rechargeable Zn-air battery (also known as a $\mathrm{Zn}$-air fuel cell) can be recharged by directly refueling active $\mathrm{Zn}$ anode into the cell. $\mathrm{Zn}$ serving as fuel is stored in a storage tank and fed to the cell. In this configuration, dendritic $\mathrm{Zn}$ formation inside the cell is avoided because $\mathrm{Zn}$ is regenerated in other places, such as an electrolyzer. Further, the air electrode of the battery does not suffer from oxygen bubbles erosion and carbon corrosion. As $\mathrm{Zn}$ is regenerated outside the cell, the mechanically rechargeable $\mathrm{Zn}$-air battery is typically fabricated as a flow battery such that the discharge product can be circulated out of the cell.

$\mathrm{Zn}$ can be regenerated by various methods. Yet, the most appropriate procedure to use with $\mathrm{Zn}$-air flow batteries is electrochemical regeneration or electrolysis. The discharge product of the batteries can be directly used as reactant of the electrolysis cell or electrolyzer. The outlet stream of a flow battery containing zincate and zinc oxide is fed to an electrolyzer to regenerate $\mathrm{Zn}$. The regenerated $\mathrm{Zn}$ is then refueled back into the battery. The zinc-air flow battery integrated with an electrolyzer can be operated as an ESS. Technologies based on mechanically rechargeable $\mathrm{Zn}$-air flow batteries and $\mathrm{Zn}$ regeneration have been developed progressively. Smedley and Zhang (2007) proposed an integrated system of $\mathrm{Zn}$-air fuel cells and electrolyzers which was designed to serve as a source of an emergency power backup system. The 12-cell-stacks system was able to provide a power output of $1.8 \mathrm{~kW}$ for $12 \mathrm{~h}$. Recently, the ESS based on Zn-air flow batteries was developed by Amunátegui et al. (2018). A 1 $\mathrm{kW}, 4 \mathrm{kWh}$ Zn-air flow battery pilot plant was demonstrated having $40 \%$ round-trip efficiency and 2,000 cycles, respectively. It was observed that the coulombic efficiency was reduced by $18 \%$ because of shunt current phenomenon.

Previously, mathematical models for different types of $\mathrm{Zn}$ air batteries were proposed to study the influence of various parameters. Mao and White (1992) developed a model of a primary $\mathrm{Zn}$-air battery to investigate the behavior of the battery concerning several design parameters. Their results showed that the utilization of $\mathrm{Zn}$ was restricted by the depletion of hydroxide ion $\left(\mathrm{OH}^{-}\right)$and significantly depended on the $\mathrm{Zn}$ loading in the electrode. Deiss et al. (2002) proposed a onedimensional mathematical model of a rechargeable $\mathrm{Zn}$-air battery and indicated that the redistribution and shape change of $\mathrm{Zn}$ and $\mathrm{ZnO}$ leads to a non-uniform $\mathrm{Zn}$ electrode. The shape change proceeded as the battery cycle progressed forward. Nevertheless, the redistribution rate slowed down when the number of cycles increased. Schröder and Krewer (2014) introduced a mathematical model for a secondary $\mathrm{Zn}$-air battery to examine the impact of air composition under isothermal operation.

Significant performance evaluations of $\mathrm{Zn}$ electrolysis include the morphology of $\mathrm{Zn}$ and the coulombic efficiency of the process (Savaskan et al., 1992; Simičić et al., 2000; Lee et al., 2006; Sharifi et al., 2009; Gavrilović-Wohlmuther et al., 2015). Wang et al. (2015a) also proposed an electrochemical phase field model for the simulation of $\mathrm{Zn}$ dendritic growth. The results showed that dendrite growth could be controlled by manipulating the concentration gradient of $\mathrm{Zn}$ ion. Moreover, dendrite growth could be suppressed by pulsed-current charging and flowing electrolyte (Garcia et al., 2017). Besides, the growth of oxygen bubbles during recharge of the $\mathrm{Zn}$-air battery was studied. It was found that the oxygen bubble coalescence could be inhibited by the flowing electrolyte.

$\mathrm{Zn}$-air batteries are preferably operated using an alkaline electrolyte. One crucial issue that occurs in alkaline $\mathrm{Zn}$-air cells is corrosion of the $\mathrm{Zn}$ anode due to hydrogen evolution reaction (HER). This is known as self-corrosion of the $\mathrm{Zn}$ anode (Wongrujipairoj et al., 2017). Moreover, this reaction consumes the electrolyte and decreases the utilization efficiency of $\mathrm{Zn}$. In other words, hydrogen evolution contributes to the coulombic efficiency loss during both charging and discharging processes. Saleh et al. (1997) developed a model of alkaline $\mathrm{Zn}$ electrowinning considering HER to study the effects of different operating parameters. Besides, Dundálek et al. (2017) proposed a model of $\mathrm{Zn}$ electrodeposition from a flowing alkaline electrolyte by considering HER and limiting current density of $\mathrm{Zn}$ reduction. 
The model was used to examine the relationship between HER and the morphology of $\mathrm{Zn}$ deposited. Nevertheless, HER has not been addressed previously in a mathematical model of a $\mathrm{Zn}$-air flow battery.

This work aims to develop a mathematical model of a Zn-air flow battery integrated with an electrolyzer. Hydrogen evolution reaction as a parasitic reaction is also considered in the model. The developed model was implemented in MATLAB and validated against the experimental data. Then, simulation was performed to examine the dynamic behavior of the battery system. The study consists of the following: (1) a brief overview of the Zn-air flow battery and $\mathrm{Zn}$ electrolyzer (2) experimental setup of the system for model validation (3) model development and validation of the model (4) simulation of the system and the effects of various parameters (5) final summary.

\section{ZINC-AIR FLOW BATTERY AND ZINC ELECTROLYZER}

A Zn-air flow battery (ZAFB) consists of two electrodes: a $\mathrm{Zn}$ anode and an air cathode, as shown in Figure 1A. The anode and cathode are separated by a separator allowing ions to transfer across the cell. Potassium hydroxide $(\mathrm{KOH})$ aqueous solution is used as an electrolyte. At the anode (negative electrode), $\mathrm{Zn}$ reacts with hydroxide ions $\left(\mathrm{OH}^{-}\right)$and forms zincate ions $\left(\mathrm{Zn}(\mathrm{OH})_{4}^{2-}\right)$ as shown in $\mathrm{R} 1$. When the concentration of zincate ion reaches its solubility limit, zinc oxide $(\mathrm{ZnO})$ precipitation reaction proceeds, as presented in R2. Hydrogen evolution reaction (HER) is also considered as a parasitic reaction on the $\mathrm{Zn}$ electrode. Water receives electrons and converts to hydrogen $\left(\mathrm{H}_{2}\right)$ and hydroxide ions, as shown in R3. HER combined with $\mathrm{Zn}$ dissolution reaction results in $\mathrm{Zn}$ corrosion, as shown in $\mathrm{R} 4$. At the cathode (positive electrode), oxygen reduction reaction (ORR) consumes oxygen $\left(\mathrm{O}_{2}\right)$ and water and produces hydroxide ions as described in R5. As the battery discharges, electrons are released from reaction $\mathrm{R} 1$ and received by reaction $\mathrm{R} 5$. Both reactions proceed and generate electricity.

$$
\begin{array}{rc}
\text { Zn electrode : } & \mathrm{Zn}+4 \mathrm{OH}^{-} \stackrel{r_{\mathrm{Zn}}}{\leftrightarrow} \mathrm{Zn}(\mathrm{OH})_{4}{ }^{2-}+2 e^{-} \\
\mathrm{Zn}(\mathrm{OH})_{4}{ }^{2-} \stackrel{r_{\mathrm{ZnO}}}{\leftrightarrow} \mathrm{ZnO}+2 \mathrm{OH}^{-}+\mathrm{H}_{2} \mathrm{O}
\end{array}
$$

The $\mathrm{Zn}$ electrolyzer, as shown in Figure 1B, consists of a $\mathrm{Zn}$ regeneration electrode (negative electrode) and an air electrode (positive electrode). The charge current is supplied to the electrolyzer inducing the reverse reactions of ZAFB to proceed: zincate ions as a reactant are converted back to $\mathrm{Zn}$ and hydroxide ions at the negative electrode (a reversion of R1). HER (R3) also significantly affects performance of the electrolyzer because water in the electrolyte can receive electrons directly from the charge current. At the positive electrode, oxygen evolution reaction (OER; a reversion of R5) converts hydroxide ions into oxygen and water.

ZAFB integrated with the $\mathrm{Zn}$ electrolyzer can be used as an energy storage system. In Figure 2, the integrated system of ZAFB connecting with $\mathrm{Zn}$ electrolyzer is illustrated. The electrolyte circulates between the battery and the electrolyzer. During discharge, ZAFB consumes $\mathrm{Zn}$ and produces zincate ion. The effluent from ZAFB, containing a high concentration of zincate ion, is fed into the electrolyzer. The electrolyzer consumes electricity in order to regenerate $\mathrm{Zn}$. Zincate ions are then converted to $\mathrm{Zn}$. In comparison, the effluent from the electrolyzer, containing a lower concentration of zincate ion, is fed into ZAFB. Besides, $\mathrm{Zn}$ regenerated from the electrolyzer is mechanically transferred to the ZAFB.

\section{EXPERIMENTAL SETUP}

The model developed in this work was validated against experimental data obtained from a Zn-air flow battery and a Zn electrolyzer. The experimental setup of the battery included a stack arrangement with a $\mathrm{Zn}$ anode plate, a separator and an air cathode. The $\mathrm{Zn}$ anode consisted of $10 \mathrm{~g} \mathrm{Zn}$ granules with an average diameter of $0.8 \mathrm{~mm}$ loaded inside a 100 -mesh stainless steel pouch functioning as a current collector. The area of the current collector was $10 \mathrm{~cm}^{2}$. The separator was prepared by casting $2 \mathrm{~g}$ of $24 \mathrm{wt}$ \% poly(vinyl acetate) (PVAc) aqueous solution over both sides of a filter paper and then dried in an oven at $55^{\circ} \mathrm{C}$ for $10 \mathrm{~min}$. The air cathode plate consisted of three layers: namely, a gas diffusion layer, a cathode current collector and a catalyst layer. Nickel foam ( $0.5 \mathrm{~mm}$ thick with $100 \mathrm{PPI})$ was employed as the cathode current collector. The gas diffusion layer was fabricated by casting a slurry mixture of $4 \mathrm{~g}$ carbon black, $4 \mathrm{~g}$ PTFE powder and $2 \mathrm{~g}$ glucose in $50 \mathrm{ml}$ ethanol on one side of the nickel foam. The coated nickel foam was then heat-pressed at $350^{\circ} \mathrm{C}$ for $15 \mathrm{~min}$ using a manual hot press machine. Then, the catalyst layer was fabricated on the other side of the nickel foam by adding a slurry mixture of $3 \mathrm{~g} \mathrm{MnO}_{2}$ and $7 \mathrm{~g}$ carbon black in the binder dissolved solvent. The solvent was prepared by dissolving $1 \mathrm{~g}$ poly styrene-co-butadiene (4\% butadiene, Sigma Aldrich) as a binder in $50 \mathrm{ml}$ toluene. The catalyst coated cathode was then annealed at $110^{\circ} \mathrm{C}$ in an oven. The gas diffusion layer exhibited good hydrophobicity. The hydrophobicity of the gas diffusion layer prevents leakage of the electrolyte and water flooding in the cathode. This layer also allows oxygen gas from the atmosphere to permeate through the cell. The active area of the cathode was $10 \mathrm{~cm}^{2}$. $\mathrm{KOH}$ aqueous solution $(7 \mathrm{M})$ was used as the electrolyte. The electrolyte with a total volume of $150 \mathrm{~mL}$ was fed through the cell at a circulation rate of $50 \mathrm{~mL} / \mathrm{min}$ using a peristaltic pump.

The experimental setup of the electrolyzer is similar to the battery. The electrolyzer included a stack arrangement with a cathode plate, a separator and an anode. The cathode plate is made of stainless steel with an active area of $10 \mathrm{~cm}^{2}$. The separator was prepared by casting $2 \mathrm{~g}$ of $24 \mathrm{wt}$.\% PVAc aqueous solution over both sides of a filter paper and then dried in an oven 

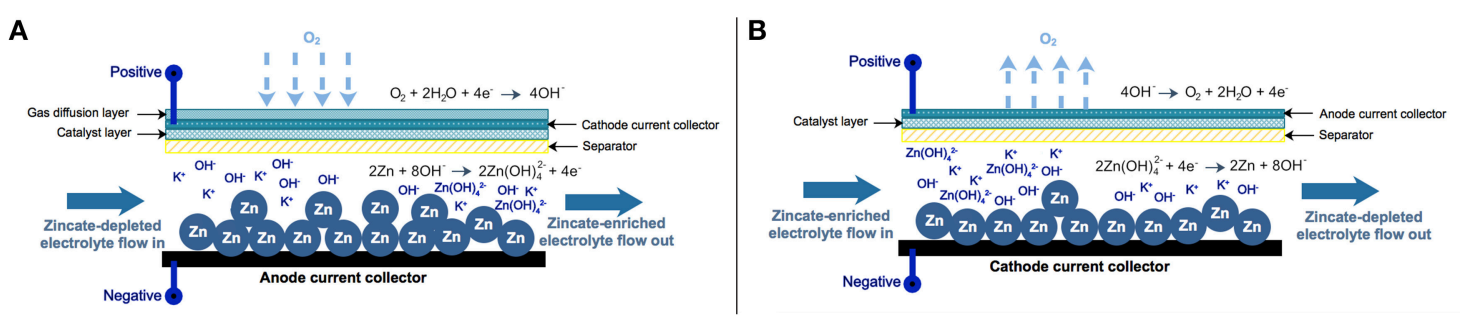

FIGURE 1 | Schematic diagram of zinc-air flow battery and zinc electrolyzer: (A) zinc-air flow battery and (B) zinc electrolyzer.

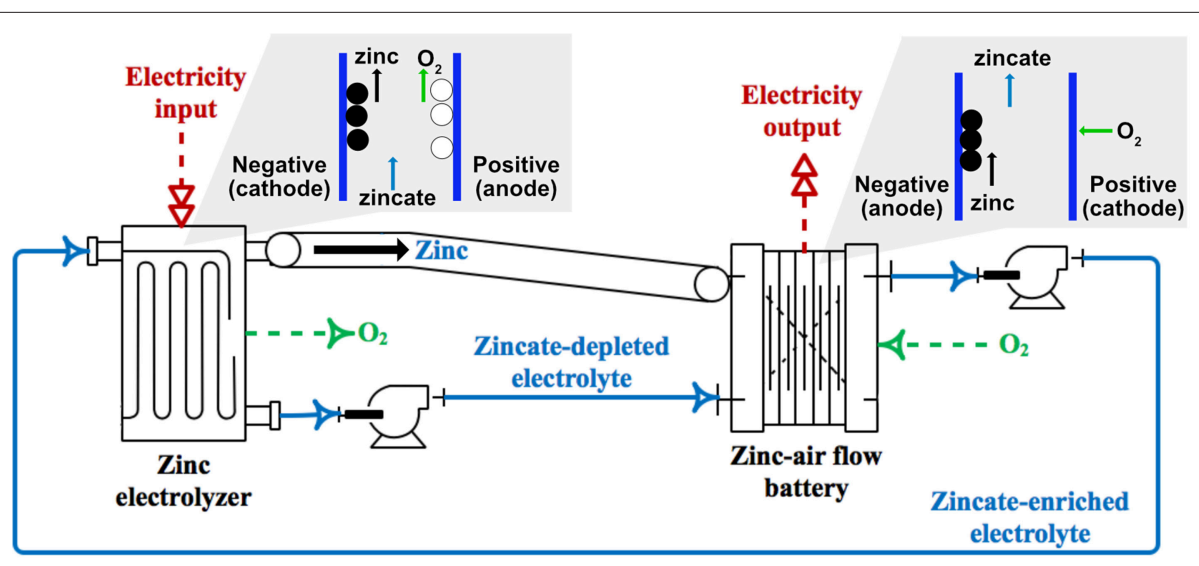

FIGURE 2 | Schematic diagram of zinc-air flow battery integrated with zinc electrolyzer.

at $55^{\circ} \mathrm{C}$ for $10 \mathrm{~min}$. The anode was made of nickel foam $(0.5 \mathrm{~mm}$ thick with $100 \mathrm{PPI}$ ) with an area of $10 \mathrm{~cm}^{2}$.

To validate the mathematical models of $\mathrm{ZAFB}$ and $\mathrm{Zn}$ electrolyzer, the polarization characteristic of ZAFB was examined. The cell voltage and current were measured by a BA500 battery analyzer using BA500WIN software. The current input can be adjusted manually and cell voltage is measured at the selected current continuously. The data of cell voltage was collected every second. For one current value, the voltage data had been collected for $10 \mathrm{~s}$ and 10 voltage values were used to calculate the average cell voltage. After that, the current value was changed to the next value. To measure the overpotential of the electrodes, a mercury/mercury oxide electrode was used as a reference electrode. The overpotential was calculated from the difference of potential between the reference electrode and the equilibrium potential of each electrode.

\section{MATHEMATICAL MODELS}

In this section, mathematical models of ZAFB and the $\mathrm{Zn}$ electrolyzer are described. The models were developed based on the following assumptions:

- Temperature variations are negligible: an isothermally operation at $298.15 \mathrm{~K}$ is assumed. Operation of both ZAFB and the $\mathrm{Zn}$ electrolyzer are carried out at room temperature.
- Zero-dimensional space: all variables and parameters inside the cell are independent of the location. The concentration gradient inside the cell is very small and can be neglected. This assumption is valid because the reactions are sufficiently slow; electrode reaction rate is relatively slower than mass transfer rate. Hence, homogenous concentrations in each cell are assumed. In previous literature, a similar assumption was also considered. For instance, Schröder and Krewer (2014) proposed a zero-dimensional zinc-air battery model which was used to investigate the effect of air-composition on cell performance. Dundálek et al. (2017) published a zero-dimensional model of zinc electrodeposition with flowing electrolyte.

- Negligible distance between the cells: the effluent of the electrolyzer immediately affects the ZAFB. In the same manner, the effluent of the ZAFB instantly affects the electrolyzer.

- Constant physical properties, electrode areas and thickness: material properties are assumed to be constant because the state of temperature and pressure is constant. The electrode area and thickness were also assumed to be constant as the cell design.

- Zn oxidation/reduction taking place at the $\mathrm{Zn}$ electrode and ORR/OER taking place at the air electrode: no reaction occurred outside the reaction area.

- The capacitive effects are negligible: the system is assumed to be a quasi-electroneutrality condition. 
- Ideal gas behavior: ideal gas law is applied as the system is operated at ambient pressure.

- Binary mass diffusion: the diffusion rate is determined by Fick's law.

\section{Species Balances}

The molar concentration balance of species $k$, including $\mathrm{OH}^{-}$, $\mathrm{Zn}(\mathrm{OH})_{4}^{2-}$ and $\mathrm{H}_{2} \mathrm{O}$, is expressed as in Equation (1). Superscript $j$ represents the electrode or position referring to $\mathrm{Zn}$ electrode $(j$ $=$ zinc) and air electrode $(j=$ air $)$ :

$$
\begin{aligned}
\frac{d C_{k}^{j}}{d t} & =\frac{1}{V_{\text {electrolyte }}^{j}} \cdot\left[F_{k, \text { in }}-F_{k, \text { out }}+J_{k}+\sum_{i} v_{k, i} \cdot r_{i}\right. \\
& \left.-C_{k}^{j} \frac{d V_{\text {electrolyte }}^{j}}{d t}\right]
\end{aligned}
$$

where $C_{k}$ is concentration of species $k, V_{\text {electrolyte }}$ is electrolyte volume, $F_{k}$ is molar flowrate of species $k, v_{k, i}$ is stoichiometric coefficient of species $\mathrm{k}$ in reaction $\mathrm{i}, r_{i}$ is rate of reaction $i$ $(\mathrm{mol} / \mathrm{s}) . J_{k}$ is molar transfer rate crossing between $\mathrm{Zn}$ and air electrodes of species $k$ including diffusion (diff), migration (mig) and convection (conv) and can be calculated as in Equation (2):

$$
J_{k}=J_{k}^{\mathrm{diff}}+J_{k}^{\mathrm{mig}}+J_{k}^{\mathrm{conv}}
$$

where :

$$
\begin{aligned}
J_{k}^{\text {diff }} & =D_{k} \cdot \frac{\left(C_{k}^{\text {air }}-C_{k}^{\text {zinc }}\right)}{\delta_{\text {sep }}} \cdot \varepsilon_{\text {sep }} \cdot A_{\text {sep }} \\
J_{k}^{\text {mig }} & =\frac{t_{k}}{z_{k}^{ \pm} F} \cdot i^{\text {cell }} \cdot \varepsilon_{\text {sep }} \cdot A_{\text {sep }} \\
J_{k}^{\text {conv }} & =F_{\text {conv }} \cdot C_{k}^{\text {zinc }}
\end{aligned}
$$

where $D_{k}$ is diffusivity of species $k, \varepsilon_{\text {sep }}$ is porosity of separator, $A_{\text {sep }}$ is area of separator, $\delta_{\text {sep }}$ is thickness of separator, $t_{k}$ is transference number of ion $k, z_{k}^{ \pm}$is ion number of species $k, F$ is Faraday constant, $i^{\text {cell }}$ is current density, $F_{\text {conv }}$ is convective volume flow crossing between $\mathrm{Zn}$ and air electrodes.

$$
F_{\mathrm{conv}}=\sum_{k} J_{k} \cdot \bar{V}_{k}
$$

From the zero-dimensional space assumption, the outlet molar flowrate of species $k\left(F_{k \text {,out }}\right)$ can be calculated as in Equation (4). The electroneutrality conditions are applied to an ionic species charge balance, as shown in Equation (5):

$$
\begin{aligned}
F_{k, \text { out }}= & C_{k}^{\text {zinc }} \cdot V_{\text {electrolyte }}^{\text {zinc }} \cdot S V \\
& \sum_{k} z_{k}^{ \pm} C_{k}^{j}=0
\end{aligned}
$$

where $S V$ is space velocity.

The accumulation of $\mathrm{ZnO}$ is expressed by the molar balance with reaction $\mathrm{R} 2$. Solid $\mathrm{Zn}$ is calculated in the same way with reaction $\mathrm{R} 1$ :

$$
\frac{d N_{\mathrm{ZnO}}}{d t}=v_{\mathrm{ZnO}, 2} \cdot r_{\mathrm{ZnO}}
$$

$$
\frac{d N_{\mathrm{Zn}}}{d t}=v_{\mathrm{Zn}, 1} \cdot r_{\mathrm{Zn}}
$$

where $N_{\mathrm{ZnO}}$ is moles of $\mathrm{ZnO}, N_{\mathrm{Zn}}$ is moles of $\mathrm{Zn}$.

\section{Rates of Reactions}

The reaction rates of reaction $\mathrm{R} 1, \mathrm{R} 3$ and $\mathrm{R} 5$ are modeled by Faradaic reaction approach as expressed in Equations (8-10), respectively:

$$
\begin{aligned}
& r_{\mathrm{Zn}}=\frac{i_{\mathrm{Zn}} \cdot A_{\mathrm{zinc}}}{n_{e} F} \\
& r_{\mathrm{H}}=\frac{i_{\mathrm{H}} \cdot A_{\mathrm{zinc}}}{n_{e} F} \\
& r_{\mathrm{air}}=\frac{i_{\mathrm{air}} \cdot A_{\mathrm{air}}}{n_{e} F}
\end{aligned}
$$

where $r_{\mathrm{Zn}}, r_{\mathrm{H}}$, and $r_{\mathrm{air}}$ are rates of reaction R1, R3, and R5, respectively. $i_{\mathrm{Zn}}, i_{\mathrm{H}}$, and $i_{\text {air }}$ are current density related to reaction $\mathrm{R} 1, \mathrm{R} 3$, and $\mathrm{R} 5$, respectively. $n_{e}$ is number of exchange electrons involved in the reaction.

For $\mathrm{ZnO}$ precipitation reaction (Equation $\mathrm{R} 2$ ), the rate of reaction is expressed by a saturation approach (Sunu and Bennion, 1980):

$$
r_{\mathrm{ZnO}}=k_{s}\left(C_{\mathrm{Zn}(\mathrm{OH})_{4}^{2-}}-C_{\mathrm{Zn}(\mathrm{OH})_{4}^{2-}}^{\mathrm{sat}}\right)
$$

where $r_{Z n O}$ is rate of reaction $\mathrm{R} 2, \mathrm{k}_{\mathrm{s}}$ is rate constant of reaction $\mathrm{R} 2$ and $\mathrm{C}_{\mathrm{Zn}(\mathrm{OH})_{4}^{2-}}^{\mathrm{sea}}$ is saturation limit concentration of $\mathrm{Zn}(\mathrm{OH})_{4}^{2-}$.

\section{Volume Change}

The solid electrode volume change can be expressed as follows:

$$
\frac{d V_{\text {solid }}^{\mathrm{zinc}}}{d t}=\frac{d N_{\mathrm{Zn}}}{d t} \cdot \bar{V}_{\mathrm{Zn}}+\frac{d N_{\mathrm{ZnO}}}{d t} \cdot \bar{V}_{\mathrm{ZnO}}
$$

The electrolyte volume change can be calculated accordingly:

$$
\begin{aligned}
\frac{d V_{\text {electrolyte }}^{\text {zinc }}}{d t} & =\sum_{k}\left(V_{\text {electrolyte }}^{\text {zinc }} \cdot \frac{d C_{k}^{\text {zinc }}}{d t}\right. \\
& \left.+C_{k}^{\text {zinc }} \cdot \frac{d V_{\text {electrolyte }}^{\text {zinc }}}{d t}\right) \cdot \bar{V}_{k} \\
\frac{d V_{\text {electrolyte }}^{\text {air }}}{d t} & =-F_{\text {conv }}+r_{\text {air }} \sum_{k} v_{k, \text { air }} \cdot \bar{V}_{k} \\
\varepsilon & =1-\frac{V_{\text {solid }}^{\text {zinc }}}{\delta_{\text {zinc }} A_{\text {elecZn }}}
\end{aligned}
$$

where $\bar{V}_{k}$ is specific molar volume of species $k, \varepsilon$ is porosity of $\mathrm{Zn}$ electrode, $V_{\text {solid }}^{\text {zinc }}$ is volume of solid $\mathrm{Zn}$ electrode, $\delta_{\text {zinc }}$ is thickness of the $\mathrm{Zn}$ electrode and $A_{\text {elec } \mathrm{Zn}}$ is surface area of the $\mathrm{Zn}$ electrode. 


\section{Cell Potential}

The cell potential $\left(E_{\text {cell }}\right)$ can be calculated from Nernst potential $\left(E_{0, \text { cell }}\right)$ minus with overpotentials as expressed in Equation (16). The included overpotentials are $\mathrm{Zn}$ activation overpotential $\left(\eta_{\text {act }}^{\text {zinc }}\right)$, air activation overpotential $\left(\eta_{\text {act }}^{\text {air }}\right)$ and ohmic overpotential $\left(\eta_{\text {ohmic }}\right)$ :

$$
\begin{aligned}
E_{\text {cell }} & =E_{0, \text { cell }}-\eta_{\mathrm{act}}^{\text {zinc }}-\eta_{\mathrm{act}}^{\mathrm{air}}-\eta_{\mathrm{ohmic}} \\
E_{0, \text { cell }} & =E^{\text {air }}-E^{\text {zinc }}
\end{aligned}
$$

where $E^{\text {air }}$ is potential of air electrode and $E^{\text {zinc }}$ is potential of the Zn electrode.

$$
\begin{aligned}
E^{\text {air }} & =E_{0}^{\text {air }}+\frac{R T}{n_{e} \cdot F} \ln \left(\frac{\left(P_{\mathrm{O}_{2}} / P^{\mathrm{ref}}\right)^{0.5}}{\left(C_{\mathrm{OH}^{-}}^{\mathrm{air}} / C^{\mathrm{ref}}\right)^{2}}\right) \\
E^{\mathrm{zinc}} & =E_{0}^{\mathrm{zinc}}+\frac{R T}{n_{e} \cdot F} \ln \left(\frac{\left(C_{\mathrm{Zn}(\mathrm{OH})_{4}^{2-}}^{\text {zinc }} / C^{\mathrm{ref}}\right)}{\left(C_{\mathrm{OH}^{-}}^{\text {zinc }} / C^{\mathrm{ref}}\right)^{4}}\right)
\end{aligned}
$$

where $E_{0}^{\text {air }}$ is standard electrode potential of air electrode, $E_{0}^{\text {zinc }}$ is standard electrode potential of the $\mathrm{Zn}$ electrode, $P_{\mathrm{O}_{2}}$ is partial pressure of oxygen, $P^{\text {ref }}$ is reference state pressure and $C^{\text {ref }}$ is reference state concentration.

\section{Activation Loss}

The activation loss of $\mathrm{Zn}$ electrode $\left(\eta_{\text {act }}^{\text {zinc }}\right)$ can be calculated from the total current at $\mathrm{Zn}$ electrode including $\mathrm{Zn}$ dissolution or regeneration $\left(i_{\mathrm{Zn}}\right)$ and $\operatorname{HER}\left(i_{\mathrm{H}}\right)$, as described in Equations (20-25):

$$
\begin{aligned}
\frac{d \eta_{\mathrm{act}}^{\mathrm{zinc}}}{d t} \cdot C_{\mathrm{DL}}^{\mathrm{zinc}}= & i^{\text {cell }}-\left(i_{\mathrm{Zn}}+i_{\mathrm{H}}\right) \\
i_{\mathrm{Zn}}= & i_{0}^{\mathrm{zinc}} \cdot\left[\exp \left(\frac{\alpha_{\mathrm{zinc}} n_{e} F}{R T} \eta_{\mathrm{act}}^{\mathrm{zinc}}\right)-\left(\frac{C_{\mathrm{Zn}(\mathrm{OH})_{4}^{2-}, s}}{C_{\mathrm{Zn}(\mathrm{OH})_{4}^{2-}, b}}\right)\right. \\
& \left.\exp \left(-\frac{\left(1-\alpha_{\mathrm{zinc}}\right) n_{e} F}{R T} \eta_{\mathrm{act}}^{\mathrm{zinc}}\right)\right] \\
i_{\mathrm{H}}= & i_{0}^{\mathrm{H}} \cdot\left[\exp \left(\frac{\alpha_{\mathrm{H}} n_{e, \mathrm{H}} F}{R T} \eta_{\mathrm{H}}\right)\right. \\
& \left.-\exp \left(-\frac{\left(1-\alpha_{\mathrm{H}}\right) n_{e, \mathrm{H}} F}{R T} \eta_{\mathrm{H}}\right)\right]
\end{aligned}
$$

where $C_{\mathrm{DL}}^{\text {zinc }}$ is double layer capacitance of the $\mathrm{Zn}$ electrode, $i_{0}^{\text {zinc }}$ is exchange current density of the $\mathrm{Zn}$ electrode, $i_{0}^{\mathrm{H}}$ is exchange current density of HER, $\alpha$ is charge transfer coefficient, $C_{\mathrm{Zn}(\mathrm{OH})_{4}^{2-}, s}$ is concentration of zincate ion at the electrode surface, $C_{\mathrm{Zn}(\mathrm{OH})_{4}^{2-}, b}$ is concentration of zincate ion in the bulk electrolyte and $\eta_{\mathrm{H}}$ is overpotential of HER at the $\mathrm{Zn}$ electrode which can be calculated from Equations (23-25).

$$
\begin{aligned}
\eta_{\mathrm{H}} & =\eta_{\mathrm{act}}^{\mathrm{zinc}}+\Delta E_{\mathrm{ZH}} \\
\triangle E_{\mathrm{ZH}} & =E^{\mathrm{zinc}}-E^{\mathrm{H}} \\
E^{\mathrm{H}} & =E_{0}^{\mathrm{H}}-\frac{R T}{n_{e} \cdot F} \ln \left(\frac{C_{\mathrm{OH}^{-}}^{\mathrm{zinc}}}{C^{\mathrm{ref}}}\right)
\end{aligned}
$$

where $E_{\mathrm{ZH}}$ is potential difference between the $\mathrm{Zn}$ electrode reaction and $\mathrm{HER}, E^{\mathrm{H}}$ is electrode potential of $\mathrm{HER}, E_{0}^{\mathrm{H}}$ is standard electrode potential of HER. The exchange current density $\left(i_{0}^{\text {zinc }}\right)$ of the $\mathrm{Zn}$ electrode can be calculated from Equations (26-29). The reference exchange current density $\left(i_{0}^{\mathrm{Zn}, \mathrm{ref}}\right)$ can be calculated from a correlation between exchange current density and concentration of $\mathrm{OH}^{-}$fitted with experimental data by Dirkse and Hampson (1972) as determined in Equation (26):

$$
\begin{aligned}
i_{0}^{\mathrm{Zn}, \mathrm{ref}} & =0.0281+0.0613 C_{\mathrm{OH}^{-}}-0.0041 C_{\mathrm{OH}^{-}}{ }^{2} \\
X_{\text {zinc }} & =\frac{V_{\text {solid,Zn }}{ }^{2 / 3}}{V_{\text {solid,Zn }}{ }^{2 / 3}+V_{\text {solid,ZnO }}{ }^{2 / 3}} \\
a_{s} & =a_{0}\left(\frac{1-\varepsilon}{1-\varepsilon_{0}}\right)^{2 / 3} \\
i_{0}^{\text {zinc }} & =i_{0}^{\text {ref,zinc }} a_{s} X_{\text {zinc }}
\end{aligned}
$$

where $X_{\text {zinc }}$ is active surface fraction of $\mathrm{Zn}$ in solid phase, $V_{\text {solid,k }}$ is volume of solid species $\mathrm{k}, a_{s}$ is solid-solution interface area per unit volume, $a_{0}$ is initial solid-solution interface area per unit volume and $\varepsilon_{0}$ is initial porosity of the $\mathrm{Zn}$ electrode. Equation (21) expressed the current of $\mathrm{Zn}$ electrode including both oxidation and reduction. For electrolyzer, the term $\left(\frac{C_{\mathrm{Zn}(\mathrm{OH})_{4}^{2-}, s}}{C_{\mathrm{Zn}(\mathrm{OH})_{4}^{2-}, b}}\right)$ refers to the diffusion limit of zincate ion in $\mathrm{Zn}$ reduction reaction (Ito et al., 2012; Dundálek et al., 2017). The concentration of zincate ion at the electrode surface $\left(C_{\mathrm{Zn}(\mathrm{OH})_{4}^{2-},{ }_{s}}\right)$ and bulk electrolyte $\left(C_{\mathrm{Zn}(\mathrm{OH})_{4}^{2-}, b}\right)$ can be described as in Equations (30) and (31):

$$
\begin{aligned}
\frac{d C_{\mathrm{Zn}(\mathrm{OH})_{4}^{2-}, s}}{d t}= & \frac{1}{V_{\text {electrolyte }}}\left[r_{\mathrm{Zn}}-D_{\mathrm{Zn}(\mathrm{OH})_{4}^{2-}, \text { elec }}\right. \\
& \times \frac{\left(C_{\mathrm{Zn}(\mathrm{OH})_{4}^{2-}, s}-C_{\mathrm{Zn}(\mathrm{OH})_{4}^{2-}, b}\right)}{\delta_{\mathrm{Zn}(\mathrm{OH})_{4}^{2-}, \mathrm{diff} A_{\text {elecZn }}}} \\
& \left.+C_{\mathrm{Zn}(\mathrm{OH})_{4}^{2-}, s} \frac{d V_{\text {electrolyte }}}{d t}\right] \\
\frac{d C_{\mathrm{Zn}(\mathrm{OH})_{4}^{2-}, b}=}{d t} & \frac{1}{V_{\text {electrolyte }}}\left[F_{\mathrm{Zn}(\mathrm{OH})_{4}^{2-}, \text { in }}-F_{\mathrm{Zn}(\mathrm{OH})_{4}^{2-}, \text { out }}-r_{\mathrm{ZnO}}\right. \\
& +D_{\mathrm{Zn}(\mathrm{OH})_{4}^{2-}, \text { elec }} \frac{\left(C_{\mathrm{Zn}(\mathrm{OH})_{4}^{2-}, s}-C_{\mathrm{Zn}(\mathrm{OH})_{4}^{2-}, b}\right)}{\delta_{\mathrm{Zn}(\mathrm{OH})_{4}^{2-}, \text { diff }^{2} A_{\text {elec }}}} \\
& \left.+C_{\mathrm{Zn}(\mathrm{OH})_{4}^{2-}, s} \frac{\left.d V_{\text {electrolyte }}\right]}{d t}\right]
\end{aligned}
$$

where $D_{\mathrm{Zn}(\mathrm{OH})_{4}^{2-} \text {,elec }}$ is diffusivity of zincate ion in electrolyte. The

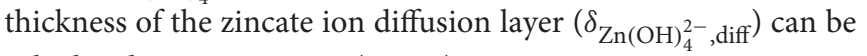
calculated as in Equations (32-35):

$$
\begin{aligned}
\delta_{\mathrm{Zn}(\mathrm{OH})_{4}^{2-}, \mathrm{diff}} & =\frac{d_{h}}{S h} \\
S h & =1.85\left(\frac{d_{h}}{L} \operatorname{ReSc}\right)^{1 / 3}
\end{aligned}
$$




$$
\begin{aligned}
& R e=\frac{d_{h} v \rho_{\mathrm{elec}}}{\mu} \\
& S c=\frac{\mu}{D_{\mathrm{Zn}(\mathrm{OH})_{4}^{2-},{ }_{\text {elec }} \rho_{\mathrm{elec}}}}
\end{aligned}
$$

where $D_{\mathrm{Zn}(\mathrm{OH})_{4}^{2-}, \text { elec }}$ is the diffusion coefficient of zincate in electrolyte, $C_{\mathrm{Zn}(\mathrm{OH})_{4}^{2-}, \mathrm{b}}$ is concentration of zincate in bulk electrolyte, $\delta_{\mathrm{Zn}(\mathrm{OH})_{4}^{2-} \text {, diff }}$ is the thickness of zincate ion diffusion layer, $d_{h}$ is hydraulic diameter, $S h$ is Sherwood number, Re is Reynolds number, Sc is Schmidt number, $v$ is electrolyte velocity, $\mu$ is viscosity of electrolyte, and $\rho_{\text {elec }}$ is density of electrolyte.

The activation loss of air electrode $\left(\eta_{\text {act }}^{\text {air }}\right)$ can be calculated accordingly:

$$
\begin{aligned}
\frac{d \eta_{\mathrm{act}}^{\text {air }}}{d t} \cdot C_{\mathrm{DL}}^{\text {air }} & =i^{\text {cell }}-i_{\text {air }} \\
i_{\text {air }} & =i_{0}^{\text {air }} \cdot\left[\left(\frac{C_{\mathrm{O}_{2}, \mathrm{~s}}}{C_{\mathrm{O}_{2}, \text { atm }}}\right) \exp \left(\frac{\alpha_{\text {air }} n_{e} F}{R T} \eta_{\text {act }}^{\text {air }}\right)\right. \\
& \left.-\exp \left(-\frac{\left(1-\alpha_{\text {air }}\right) n_{e} F}{R T} \eta_{\text {act }}^{\text {air }}\right)\right]
\end{aligned}
$$

where $C_{\mathrm{DL}}^{\text {air }}$ is double layer capacitance of air electrode, $i_{\text {air }}$ is current density respecting to air electrode reaction, $C_{\mathrm{O}_{2} \text {,atm }}$ is concentration of oxygen in the atmosphere. The exchange current density of air electrode $\left(i_{0}^{\text {air }}\right)$ is expressed as in Equation (38). The oxygen concentration at catalyst surface $\left(C_{\mathrm{O}_{2}, \mathrm{~s}}\right)$ can be calculated by using molar concentration balance as described in Equation (39).

$$
\begin{aligned}
i_{0}^{\text {air }} & =i_{0}^{\text {air,ref }} a_{c} \delta_{\text {active }} \\
\frac{d C_{\mathrm{O}_{2}, \mathrm{~s}}}{d t} & =\frac{1}{V_{\text {electrolyte }}} \cdot\left[-0.5 r_{\text {air }}-D_{\mathrm{O}_{2}, \text { air }} \frac{\left(C_{\mathrm{O}_{2}, \mathrm{~s}}-C_{\mathrm{O}_{2}, \mathrm{~atm}}\right)}{\delta_{\mathrm{GDL}} A_{\mathrm{air}}}\right. \\
& \left.+C_{\mathrm{O}_{2}, \mathrm{~s}} \frac{d V_{\text {electrolyte }}^{\text {air }}}{d t}\right]
\end{aligned}
$$

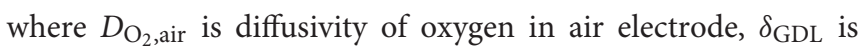
thickness of gas diffusion layer of air electrode, and $A_{\text {air }}$ is active surface area of air electrode.

\section{Ohmic Loss}

The ohmic loss $\left(\eta_{\text {ohmic }}\right)$ is expressed by Ohmic's law. The total ohmic resistance $\left(R_{\text {ohmic }}\right)$ is calculated from the conductivity and resistivity of the chemical species and cell components involved. Anode conductivity is accounted for by the solid species conductivity and mole fraction in solid electrode.

$$
\begin{aligned}
\eta_{\text {ohmic }} & =i^{\text {cell }} \cdot \mathrm{A}_{\text {cell }} \cdot R_{\text {ohmic }} \\
R_{\text {ohmic }} & =\frac{\delta_{\text {zinc }}}{\sigma_{\text {anode }} A_{\text {zinc }}}+\frac{\delta_{\text {electrolyte }}}{\sigma_{\text {electrolyte }} A_{\text {electrolyte }}} \\
& +\frac{\delta_{\text {air }}}{\sigma_{\text {cathode }} A_{\text {air }}}+R_{\text {comp }} \frac{\delta_{\text {comp }}}{A_{\text {cell }}}
\end{aligned}
$$

$$
\begin{aligned}
\sigma_{\text {anode }} & =\left(\frac{N_{\mathrm{Zn}}}{N_{\mathrm{Zn}}+N_{\mathrm{ZnO}}} \sigma_{\mathrm{Zn}}+\frac{N_{\mathrm{ZnO}}}{N_{\mathrm{Zn}}+N_{\mathrm{ZnO}}} \sigma_{\mathrm{ZnO}}\right)(1-\varepsilon) \\
& +\sigma_{\text {electrolyte }} \varepsilon
\end{aligned}
$$

where $\delta_{\text {zinc }}, \delta_{\text {electrolyte }}$ and $\delta_{\text {air }}$ are thickness of the Zn electrode, electrolyte channel and air electrode, respectively. $\sigma_{\text {anode, }}$, $\sigma_{\text {electrolyte }}$ and $\sigma_{\text {cathode }}$ are conductivity of $\mathrm{Zn}$ electrode, electrolyte channel and air electrode, respectively. $R_{\text {comp }}$ and $\delta_{\text {comp }}$ are resistivity and equilibrium thickness of other cell components. $\sigma_{\mathrm{Zn}}$ and $\sigma_{\mathrm{ZnO}}$ are conductivity of $\mathrm{Zn}$ and zinc oxide, respectively.

The developed model was implemented and simulated in MATLAB. The designed parameters and operating conditions are given in Table S1 in Supplementary Material. The initial conditions at $t=0 \mathrm{~s}$ are listed in Table $\mathbf{S 2}$ in Supplementary Material.

\section{RESULTS AND DISCUSSION}

\section{Model Validation}

As regards validation of the ZAFB and the electrolyzer model, two parameters, including the thickness of the active air electrode $\left(\delta_{\text {active }}\right)$ and the resistance of other cell components $\left(R_{\text {comp }}\right)$, were manually adjusted to fit the model prediction with the experimental data. The fitted values of $\delta_{\text {active }}$ and $R_{\text {comp }}$ were $30 \mu \mathrm{m}$ and $5 \Omega$. $\mathrm{cm}$, respectively. Figure $3 \mathrm{~A}$ shows the comparison of the polarization curve between simulation and experimental data of the ZAFB. It was observed that there was good agreement between the model prediction and the experimental data. The comparison of total overpotential of the electrodes between the model prediction and experimental data is displayed in Figure 3B. The overpotential of each electrode is a combination of electrode activation overpotential and the ohmic loss. It was assumed that the ohmic loss from the cathode contributes to half of the total ohmic loss of the cell. The ohmic loss from the anode also contributes to half of the total ohmic loss of the cell. The comparison was acceptable for $\mathrm{Zn}$ overpotential. In the case of the air electrode, a small offset was observed. This offset might have arisen from the ohmic loss which arbitrarily adds to the activation overpotential. The measured overpotential of the electrodes from the experiment included some part of the ohmic overpotential which cannot be distinguished from the activation overpotential. The model simulated the activation overpotential and ohmic overpotential separately. Therefore, the measured overpotentials were found to be different from the simulated overpotentials. Furthermore, the differentiation of the air electrode was reported (Schröder et al., 2016). However, this differentiation was not included in the model herein. On the part of the $\mathrm{Zn}$ electrolyzer, Figures 3C, D show the comparison of the cell potential and the absolute overpotential of the electrodes between simulation and experiment. Acceptable validity between the simulation and experimental data was observed. A small offset was still shown in the overpotential of air electrode. When charging, it was noted that the growth of oxygen bubbles at the air electrode can affect the behavior of the air electrode (Wang et al., 2015b). Nevertheless, this model does not consider the effects of oxygen bubbles. 

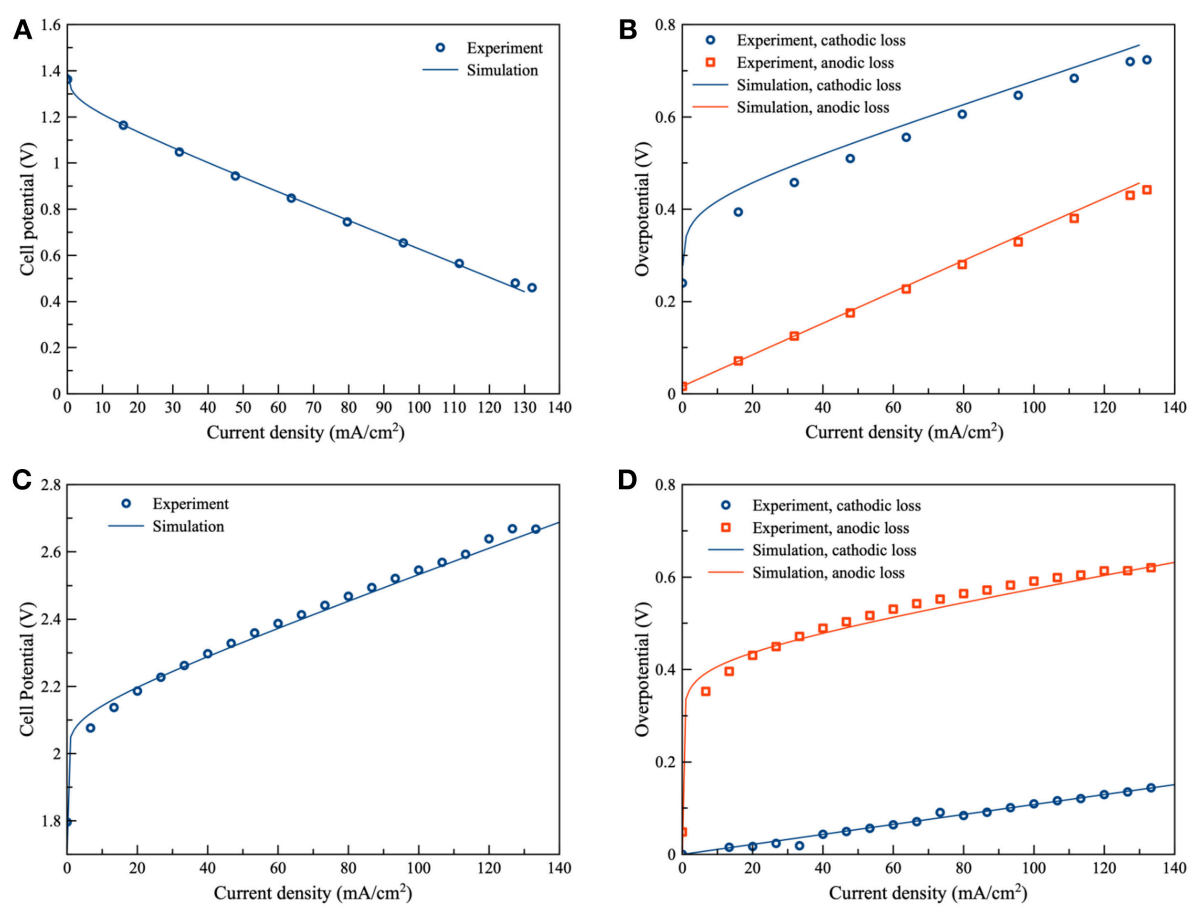

FIGURE 3 | Validation of the proposed models: (A) polarization characteristic of ZAFB (B) anode and cathode overpotential of ZAFB (C) polarization characteristic of Zn electrolyzer and (D) anode and cathode overpotential of Zn electrolyzer.
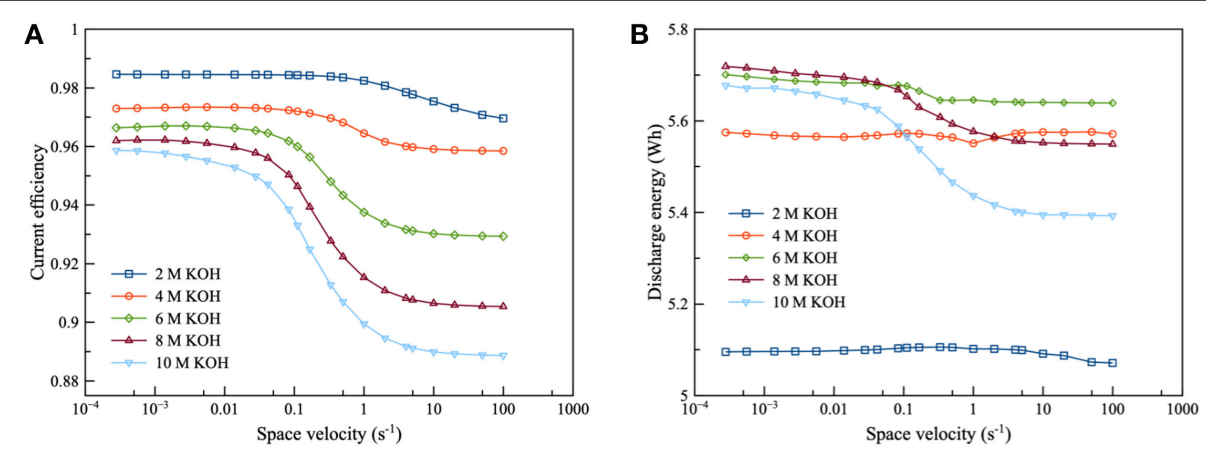

FIGURE 4 | Effects of $\mathrm{KOH}$ concentration on ZAFB using zincate ion initial concentration $0.2 \mathrm{M}$ and discharge current density of $100 \mathrm{~mA} / \mathrm{cm}^{2}$ : (A) current efficiency as a function of space velocity and (B) discharge energy as a function of space velocity.

\section{Battery Performance}

The ZAFB with $10 \mathrm{~g}$ of initial $\mathrm{Zn}(0.1538$ mole of $\mathrm{Zn})$ was simulated to analyze performance as functions of space velocity, $\mathrm{KOH}$ concentration and zincate ion initial concentration. The discharge current density was $100 \mathrm{~mA} / \mathrm{cm}^{2}$. The simulation was carried out until depletion of $\mathrm{Zn}$. The performance of ZAFB was evaluated from its current efficiency and discharge energy at the end of the simulation. The current efficiency of ZAFB is defined as the ratio of the total discharge current to the electrochemical equivalent current of the $\mathrm{Zn}$ electrode. In this case, the current efficiency was calculated as follows:

$$
\text { Current efficiency of ZAFB }=\frac{i^{\text {cell }} A_{\text {elecZn }} t_{f}}{2 F\left(N_{\mathrm{Zn}, 0}-N_{\mathrm{Zn}, f}\right)}
$$

and the discharge energy is given by:

$$
\text { Discharge energy }(\mathrm{Wh})=\frac{\sum_{t=0}^{t_{f}}\left(E_{\mathrm{cell}}\right)\left(i^{\text {cell }} A_{\mathrm{elecZn}} t_{f}\right)}{3,600}
$$

where $t_{f}$ is the total operating time in s, $N_{\mathrm{Zn}, 0}$ is initial mole of $\mathrm{Zn}$ and $N_{\mathrm{Zn}, f}$ is final mole of $\mathrm{Zn}$. 


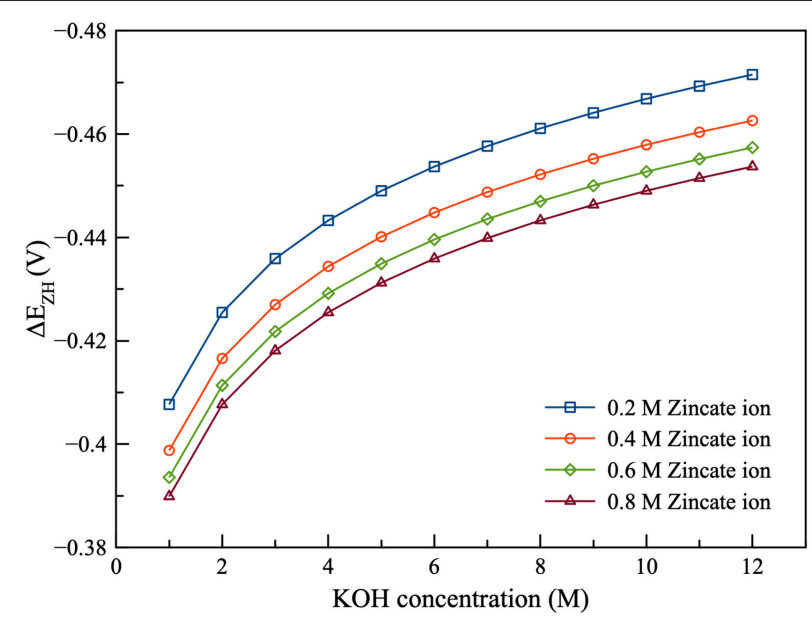

FIGURE 5 | Effects of zincate ion initial concentration on $\Delta E_{Z H}$ as a function of $\mathrm{KOH}$ concentration.

As shown in Figure 4, the current efficiency and discharge energy of ZAFB were examined as functions of $\mathrm{KOH}$ concentration and space velocity. Figure $4 \mathrm{~A}$ shows that the higher $\mathrm{KOH}$ concentration provided lower efficiency than the lower $\mathrm{KOH}$ concentration. It indicated that corrosion of the $\mathrm{Zn}$ electrode increased when the concentration of $\mathrm{KOH}$ increased. The corrosion was greater at higher $\mathrm{KOH}$ concentration because the reversible potential difference between the $\mathrm{Zn}$ electrode reaction and $\operatorname{HER}\left(\Delta E_{\mathrm{ZH}}\right)$ was negatively larger at higher $\mathrm{KOH}$ concentration, as shown in Figure 5. $\Delta E_{\mathrm{ZH}}$ contributes to HER overpotential $\left(\eta_{\mathrm{H}}\right)$ and drives the current of HER, as shown in Equations $(22,23)$, respectively. The effect of $\mathrm{KOH}$ concentration on $\mathrm{Zn}$ corrosion was also investigated by other researchers using different methods (Muralidharan and Rajagopalan, 1978; Ravindran and Muralidharan, 1995; El-Sayed et al., 2012). Muralidharan and Rajagopalan (1978) studied corrosion of zinc in sodium hydroxide solution with steady state and transient tafel extrapolation. Ravindran and Muralidharan (1995) determined the hydrogen evolution rate by gasometric method and examined the behavior of zinc in alkaline electrolyte. El-Sayed et al. (2012) proposed the corrosion study of $\mathrm{Zn}$ in alkaline solution by tafel plot and electrochemical impedance spectroscopy (EIS). The research as mentioned above is in full agreement with the result concerning the effect of $\mathrm{KOH}$ concentration on hydrogen evolution. However, when $\mathrm{KOH}$ concentration increased, it had a different effect on the discharge energy, as shown in Figure 4B. Consequently, when concentration of $\mathrm{KOH}$ reached about $6 \mathrm{M}$, it provided maximum exchange current density of $\mathrm{Zn}$ dissolution and maximum ionic conductivity. Using $\mathrm{KOH}$ concentration more or $<6 \mathrm{M}$ decreased the energy discharge of ZAFB. Thus, at $6 \mathrm{M} \mathrm{KOH}$ concentration, the maximum performance for ZAFB was achieved.

As regards the effect of flowrate, the increasing space velocity of the electrolyte provided lower current efficiency because the higher electrolyte flowrate maintained a higher concentration of $\mathrm{KOH}$ which contributed to higher corrosion. However, the flowrate exhibited less effect at lower $\mathrm{KOH}$ concentration.

Figure 6 presents the effect of zincate ion concentration on the performance of ZAFB. The results showed that increasing the concentration of zincate ion tended to increase the current efficiency and discharge energy of the battery. This was because hydrogen evolution was affected by the zincate ion concentration. Previously, Figure 5 shows the relation between $\Delta E_{\mathrm{ZH}}$ and concentration of zincate ion. When zincate ion concentration increased, $\Delta E_{\mathrm{ZH}}$ reduced due to the decrease in the reversible $\mathrm{Zn}$ electrode potential ( $\left.E^{\text {zinc }}\right)$. According to the previous work of Shivkumar et al. (1995), it was reported that adding $\mathrm{ZnO}$ reduced hydrogen evolution and $\mathrm{Zn}$ dissolution. The previous work came to the same conclusion as the result herein.

\section{Electrolyzer Performance}

In the case of the electrolyzer, simulation was performed in order to examine the effects of space velocity, $\mathrm{KOH}$ concentration and zincate ion concentration using a charge current density of 100 $\mathrm{mA} / \mathrm{cm}^{2}$. The target amount of regenerated $\mathrm{Zn}$ was $10 \mathrm{~g}$. The simulation was terminated when it reached the target amount of $\mathrm{Zn}$. The current efficiency of the electrolyzer is the ratio of the equivalent current for $\mathrm{Zn}$ regeneration to the total applied current. The current efficiency and charge energy of electrolyzer is expressed by:

$$
\begin{aligned}
\text { Current efficiency of electrolyzer } & =\frac{2 F\left(N_{\mathrm{Zn}, f}-N_{\mathrm{Zn}, 0}\right)}{i^{\mathrm{cell}} A_{\mathrm{elecZn}} t_{f}} \\
\text { Charge energy }(\mathrm{Wh}) & =\frac{\sum_{t=0}^{t_{f}}\left(E_{\mathrm{cell}}\right)\left(-i^{\mathrm{cell}} A_{\mathrm{elecZn}} t_{f}\right)}{3,600}
\end{aligned}
$$

The performance of the $\mathrm{Zn}$ electrolyzer was evaluated by the current efficiency and the charge energy, as shown in Figure 7. It was found that the flow of the electrolyte had a significant effect on the performance of the electrolyzer. Increasing space velocity increased the current efficiency but decreased charge energy. The high flowrate was preferred because increasing flowrate reduced the diffusion film thickness of the zincate ion. Consequently, Zn reduction was promoted and HER was suppressed. As regards the effect of zincate ion concentration, current efficiency increased and charge energy decreased when the concentration of zincate ion increased. The higher zincate ion concentration provided greater driving force of the diffusion and thereby enhanced the $\mathrm{Zn}$ reduction reaction. Increasing zincate ion concentration also reduced $\Delta E_{\mathrm{ZH}}$ of HER which also suppressed the corrosion of $\mathrm{Zn}$ electrode. Many previous works have reached the same conclusion about the effect of zincate ion on $\mathrm{Zn}$ electrodeposition, as the result put forward herein (Einerhand et al., 1988; Sharifi et al., 2009; Dundálek et al., 2017). Einerhand et al. (1988) reported that the high concentration of zincate ion promoted $\mathrm{ZnO}$ layer formation on $\mathrm{Zn}$ electrode surface which protected $\mathrm{Zn}$ against corrosion. Dundálek et al. (2017) also highlighted the relation between Zn deposition morphology, electrolyte condition and HER and 

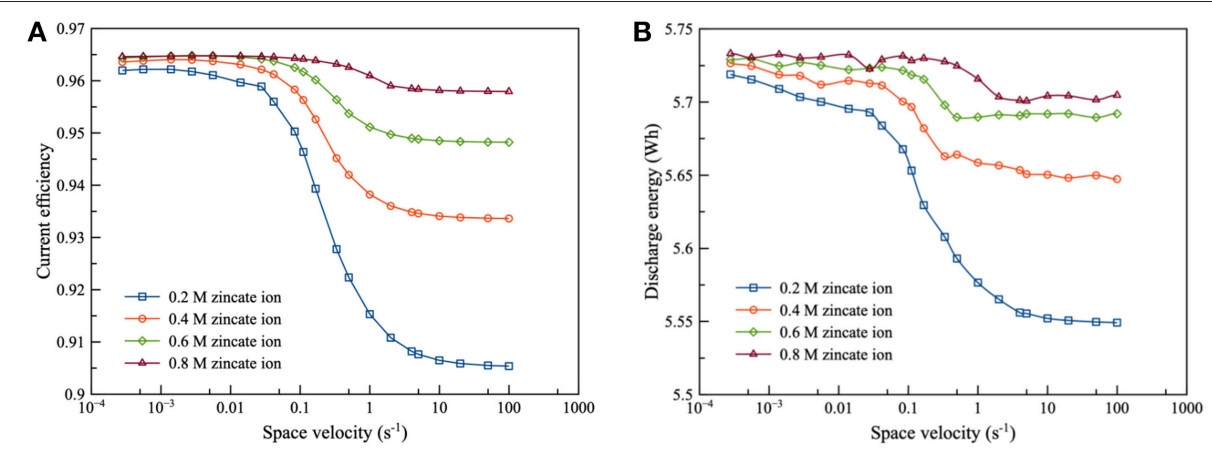

FIGURE 6 | Effects of zincate ion initial concentration on ZAFB using $8 \mathrm{M} \mathrm{KOH}$ at discharge current density of $100 \mathrm{~mA} / \mathrm{cm}^{2}$ : (A) current efficiency as a function of space velocity and (B) discharge energy as a function of space velocity.
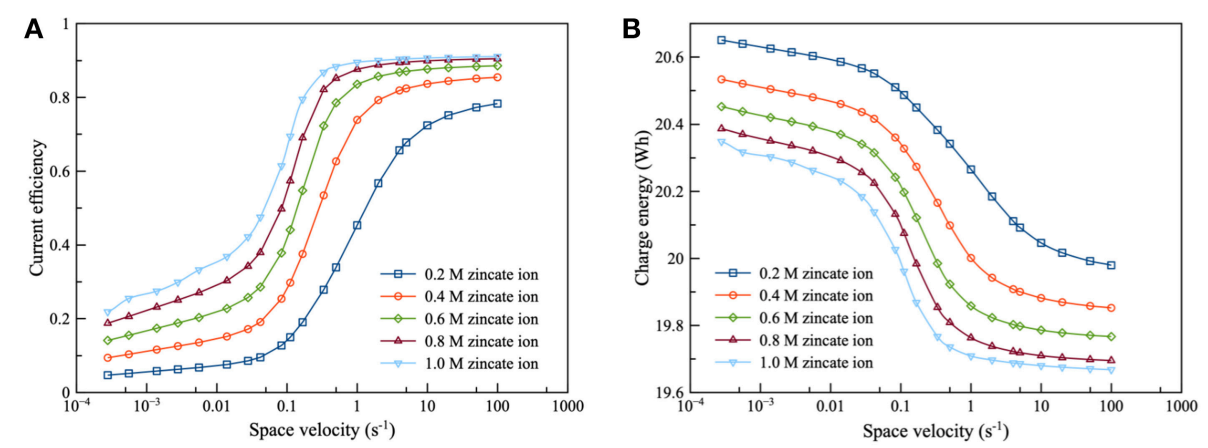

FIGURE 7 | Effects of zincate ion initial concentration on zinc electrolyzer using $8 \mathrm{M} \mathrm{KOH}$ at charge current density of $100 \mathrm{~mA} / \mathrm{cm}^{2}$ : (A) current efficiency as a function of space velocity and (B) charge energy as a function of space velocity.
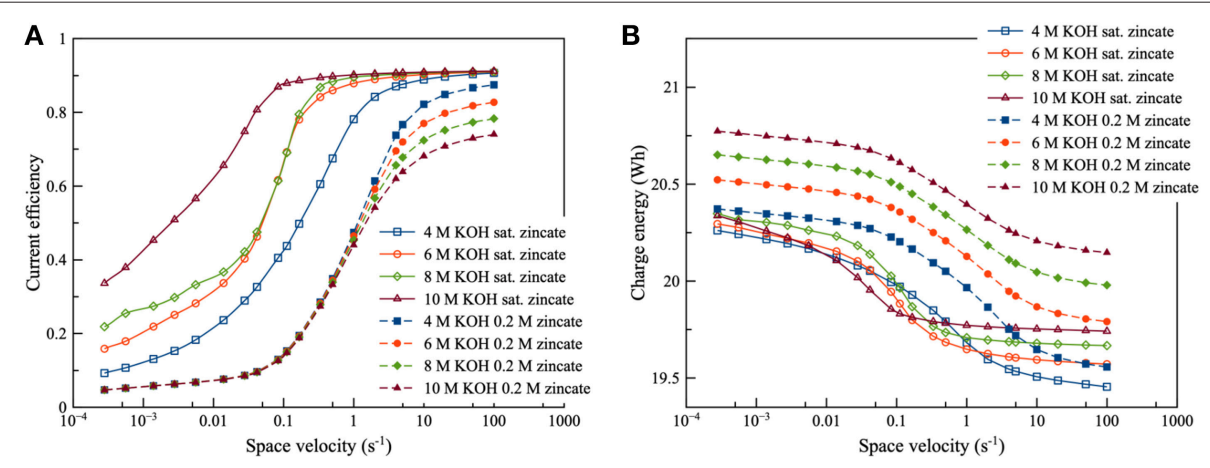

FIGURE 8 | Effects of $\mathrm{KOH}$ concentration using different zincate ion initial concentration [0.2 $\mathrm{M}$ (dotted line) and saturated zincate ion (solid line)] at discharge current density of $100 \mathrm{~mA} / \mathrm{cm}^{2}$ : (A) current efficiency as a function of space velocity and (B) charge energy as a function of space velocity.

concluded that high flowrate and zincate ion concentration were preferred for Zn electrodepositon with low HER.

Regarding the effect of $\mathrm{KOH}$ concentration, as illustrated in Figure 8, it was observed that $\mathrm{KOH}$ concentration had a complicated effect on current efficiency and charge energy. $\mathrm{KOH}$ concentration had a connection with the saturation limit of zincate ion. When zincate ion was not saturated, $\mathrm{KOH}$ concentration had little effect on current efficiency in the low flowrate region. However, a different trend was observed in the high flowrate region (space velocity above 1 per second). In the high flowrate region, increasing $\mathrm{KOH}$ concentration provided lower current efficiency due to increasing $\Delta E_{\mathrm{ZH}}$. As for the effect on charge energy, the higher $\mathrm{KOH}$ concentration needed higher charge energy because of the higher Nernst potential $\left(E_{0, \text { cell }}\right)$. Sharifi et al. (2009) also studied zinc electrolysis using various $\mathrm{KOH}$ concentration and approached to the same conclusion. When the zincate ion was saturated, the effect on current efficiency and charge energy was different from that of 
non-saturated zincate ion. $\mathrm{KOH}$ concentration had less effect in the high flowrate region, but it had a direct effect in the low flowrate region. When $\mathrm{KOH}$ concentration increased, efficiency tended to increase due to the saturation limit of zincate ion. The saturation limit increased due to the increase in $\mathrm{KOH}$ concentration. The effect of the saturation limit showed a similar trend with the effect of zincate ion concentration, as in Figure 7. The higher saturation limit provided higher efficiency.

\section{Integrated System}

The operation having an equal charge-discharge current density of $100 \mathrm{~mA} / \mathrm{cm}^{2}$ was simulated. The initial $\mathrm{Zn}$ in ZAFB was $10 \mathrm{~g}$ (0.1538 mole of $\mathrm{Zn})$. $\mathrm{Zn}$ depletion in ZAFB was the termination criterion. The current efficiency of the integrated system is defined as the ratio of the total amount of $\mathrm{Zn}$ regenerated to the total amount of $\mathrm{Zn}$ utilized, as in Equation (47). The other performance evaluation is energy efficiency which is expressed as the ratio of discharge energy to charge energy, as described in Equation (48):

Current efficiency of the integrated system

$$
\begin{aligned}
=\frac{N_{\mathrm{Zn}, f}^{\text {electrolyzer }}-N_{\mathrm{Zn}, 0}^{\text {electrolyzer }}}{N_{\mathrm{Zn}, 0}^{\text {battery }}-N_{\mathrm{Zn}, f}^{\text {battery }}} \\
\text { Energy efficiency }=\frac{\text { Discharge energy }(\mathrm{Wh})}{\text { Charge energy }(\mathrm{Wh})}
\end{aligned}
$$

Then, the performance of the integrated system was examined by considering various operating parameters i.e., space velocity, $\mathrm{KOH}$ concentration and zincate ion concentration.

The current efficiency and energy efficiency of the integrated system are as shown in Figure 9. It was observed that the efficiency trends of the integrated system were comparable with the charge efficiency trends of the electrolyzer, as illustrated in Figures 9A-C. It can be inferred that the efficiency of the integrated system is dominated by the electrolyzer. The results showed that increasing flowrate enhanced the current efficiency except at low zincate ion concentration. At low zincate concentration, the inflection point occurred at space velocity range $0.1-1 \mathrm{~s}^{-1}$ and especially at $0.2 \mathrm{M}$ zincate concentration. The condition at the bottom of the curve is the condition such that the total amount of zincate ion transferring to the electrode surface is minimum compared to the adjacent condition. The increasing flowrate had a positive effect on the energy efficiency of the system. In the case of the comparison of effect of zincate ion concentration, the higher zincate ion concentration provided better performance throughout the range of space velocity. Increasing zincate ion concentration was able to suppress HER and increase the current efficiency for both discharging and charging. At space velocity, approximately below $0.1 \mathrm{~s}^{-1}$, increasing zincate ion concentration improved energy efficiency. In contrast, at space velocity above $1 \mathrm{~s}^{-1}$, increasing zincate ion concentration provided an adverse effect on energy efficiency.

In Figure 10, the performance of the integrated system was examined: namely, from 2 to $10 \mathrm{M} \mathrm{KOH}$ concentration.
It was observed that the efficiency curve could be divided into 2 regions: the region before and after the inflection point. For the region before the inflection point, efficiency increased as $\mathrm{KOH}$ concentration increased. Zincate ion was saturated herein. Subsequently, when $\mathrm{KOH}$ concentration increased, the saturation limit of zincate ion increased. Therefore, zincate ion diffusion also improved. On the other hand, efficiency decreased as $\mathrm{KOH}$ concentration increased for the region after the inflection point. Zincate ion was not saturated in this region. Thus, the concentration of zincate ion was not much different between the various $\mathrm{KOH}$ concentration. However, HER still intensified as $\mathrm{KOH}$ concentration increased. It is evident that $8 \mathrm{M} \mathrm{KOH}$ concentration provided maximum energy efficiency. This was followed by $6 \mathrm{M} \mathrm{KOH}$ concentration. Energy efficiency was dominated by the performance of the discharge process which was influenced mainly by optimal $\mathrm{KOH}$ concentration. As mentioned previously in the section of battery performance, concentration of about 6 to $7 \mathrm{M} \mathrm{KOH}$ provided maximum exchange current density of the $\mathrm{Zn}$ electrode reaction and maximum ionic conductivity. Consequently, in the case of the integrated system, 6 and $8 \mathrm{M} \mathrm{KOH}$ concentration exhibited optimal performance.

\section{CONCLUSION}

In this work, a mathematical model of a Zn-air flow battery integrated with a $\mathrm{Zn}$ electrolyzer including the model of HER was developed to evaluate the system performance. Thereby, the following parameters were investigated: electrolyte flowrate, potassium hydroxide $(\mathrm{KOH})$ concentration and zincate ion initial concentration. Besides, the influence of the hydrogen evolution reaction (HER) on the performance of the $\mathrm{Zn}$-air energy storage system was examined. Upon investigation, it was found that $\mathrm{KOH}$ concentration had a significant effect on the performance of the battery. Further, it was noted that increasing $\mathrm{KOH}$ concentration enhanced HER and reduced the current efficiency. However, the optimal $\mathrm{KOH}$ concentration, which was about 6-7 M, provided maximum discharge energy. Increasing zincate ion initial concentration was able to suppress the HER and increase the current efficiency of the battery because of the lessening of reversible potential difference between the $\mathrm{Zn}$ electrode reaction and HER. As regards the electrolyzer, the results showed that the performance of the electrolyzer was dominated by zincate ion initial concentration and electrolyte flowrate. When zincate ion initial concentration increased together with the flowrate, current efficiency significantly increased. Further, the charge energy was reduced due to the enhancement of zincate ion diffusion to the electrode surface. Yet, increasing $\mathrm{KOH}$ concentration did not directly improve electrolyzer performance but contributed to the increment of saturation limit of zincate ion which enhanced the electrolyzer performance. For the overall integrated system, it was observed that the current efficiency of the integrated system was dominated by the electrolyzer. Therefore, increasing zincate ion initial concentration and electrolyte flowrate had a beneficial effect 

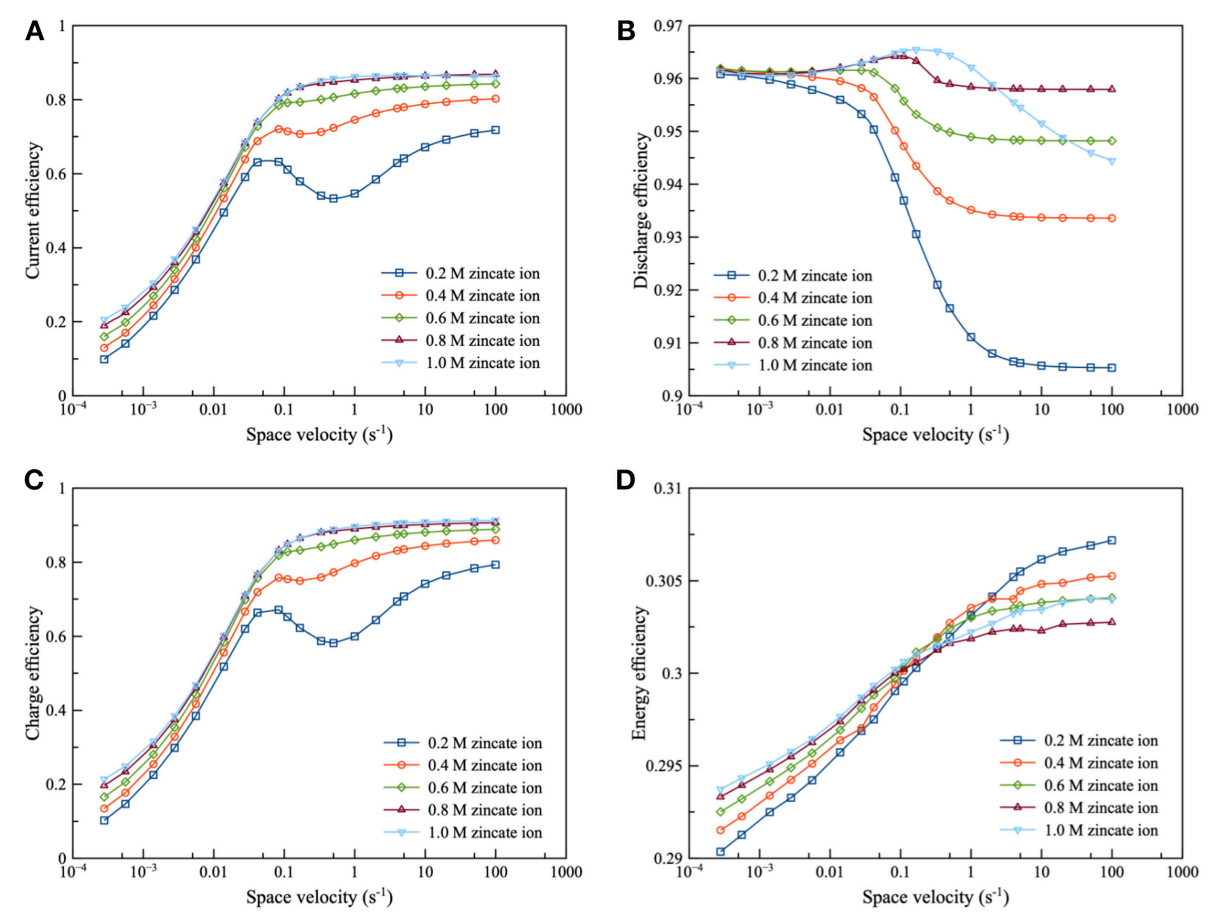

FIGURE 9 | Effects of zincate ion initial concentration using $8 \mathrm{M} \mathrm{KOH}$ at charge and discharge current density of $100 \mathrm{~mA} / \mathrm{cm}^{2}$ : (A) current efficiency as a function of space velocity (B) discharge efficiency as a function of space velocity (C) charge efficiency as a function of space velocity and (D) energy efficiency as a function of space velocity.
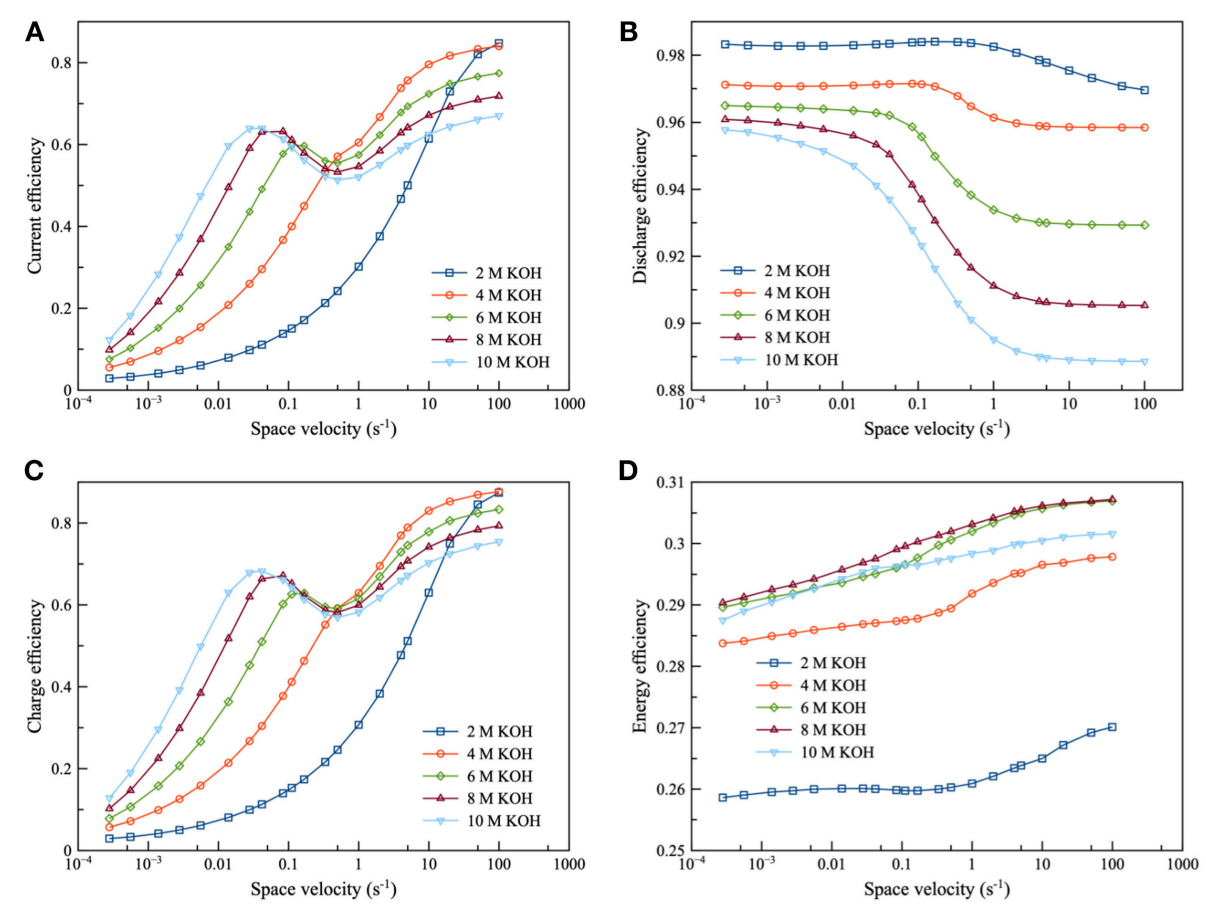

FIGURE 10 | Effects of $\mathrm{KOH}$ concentration using $0.2 \mathrm{M}$ zincate ion initial concentration at charge and discharge current density of $100 \mathrm{~mA} / \mathrm{cm}^{2}$ : (A) current efficiency as a function of space velocity (B) discharge efficiency as a function of space velocity (C) charge efficiency as a function of space velocity and (D) energy efficiency as a function of space velocity. 
on the current efficiency of the integrated system. On the other hand, the energy efficiency of the integrated system was essentially influenced by the discharging cell. Maximum energy efficiency was obtained by the optimal concentration of $\mathrm{KOH}$ similar to the discharge energy of the flow battery. The results of this work described the role that HER contributed toward the performance of the integrated system of $\mathrm{Zn}$-air flow battery and $\mathrm{Zn}$ electrolyzer. Overall, it was found that HER had a detrimental effect on the performance of the integrated system. To conclude, it can be seen that control of the operating conditions was found to be an effective way to diminish HER and extract optimal performance out of the integrated system.

\section{AUTHOR CONTRIBUTIONS}

SK conceived the research project. WL conducted the experiments and performed the simulation. $\mathrm{KB}$ conducted the experiments during revision process. Data analyses were done by WL with consultation with SK. The paper was written by WL and SK, and all authors contributed to the subsequent drafts. All authors reviewed the manuscript.

\section{REFERENCES}

Amunátegui, B., Ibáñez, A., Sierra, M., and Pérez, M. (2018). Electrochemical energy storage for renewable energy integration: zinc-air flow batteries. J. Appl. Electrochem. 48, 627-637. doi: 10.1007/s10800-017-1133-7

Bockelmann, M., Kunz, U., and Turek, T. (2016). Electrically rechargeable zincoxygen flow battery with high power density. Electrochem. Comm. 69, 24-27. doi: 10.1016/j.elecom.2016.05.013

Deiss, E., Holzer, F., and Haas, O. (2002). Modeling of an electrically rechargeable alkaline $\mathrm{Zn}$-air battery. Electrochim. Acta. 47, 3995-4010. doi: 10.1016/S0013-4686(02)00316-X

Dirkse, T. P., and Hampson, N. A. (1972). The $\mathrm{Zn}(\mathrm{II}) / \mathrm{Zn}$ exchange reaction in $\mathrm{KOH}$ solution- $\mathrm{I}$. exchange current density measurements using the galvanostatic method. Electrochim. Acta. 17, 135-141. doi: 10.1016/0013-4686(72)85014-X

Dundálek, J., Šnajdr, I., Libánský, O., Vrána, J., Pocedič, J., Mazúr, P., et al. (2017). Zinc electrodeposition from flowing alkaline zincate solutions: role of hydrogen evolution reaction. J. Power Sour. 372, 221-226. doi: 10.1016/j.jpowsour.2017.10.077

Dunn, B., Kamath, H., and Tarascon, J.-M. (2011). Electrical energy storage for the grid: a battery of choices. Science 334, 928-935. doi: 10.1126/science.1212741

Einerhand, R. E. F., Visscher, W. H. M., and Barendrecht, E. (1988). Hydrogen production during zinc deposition from alkaline zincate solutions. J. Appl. Electrochem. 18, 799-806. doi: 10.1007/BF01016034

El-Sayed, A.-R., Mohran, H. S., and Abd El-Lateef, H. M. J. M. (2012). Corrosion study of zinc, nickel, and zinc-nickel alloys in alkaline solutions by tafel plot and impedance techniques. Metallurg. Mater. Trans. A 43, 619-632. doi: 10.1007/s11661-011-0908-4

Escalante Soberanis, M. A., Mithrush, T., Bassam, A., and Mérida, W. (2018). A sensitivity analysis to determine technical and economic feasibility of energy storage systems implementation: a flow battery case study. Renew. Energy 115, 547-557. doi: 10.1016/j.renene.2017.08.082

Fu, J., Zhang, J., Song, X., Zarrin, H., Tian, X., Qiao, J., et al. (2016). A flexible solidstate electrolyte for wide-scale integration of rechargeable zinc-air batteries. Energy Environ. Sci. 9, 663-670. doi: 10.1039/C5EE03404C

Garcia, G., Ventosa, E., and Schuhmann, W. (2017). Complete prevention of dendrite formation in $\mathrm{Zn}$ metal anodes by means of pulsed charging protocols. Appl. Mater. Interfaces 9, 18691-18698. doi: 10.1021/acsami.7b01705

\section{FUNDING}

The research is supported by Chulalongkorn Academic Advancement into its Second Century Project, Chulalongkorn University. WL thanks the Chulalongkorn University Dusadeepipat scholarship.

\section{ACKNOWLEDGMENTS}

All authors thanks the support from Thailand's Office of Higher Education, Chulalongkorn University, and Government of France/Campus France under Franco-Thai Cooperation Programme in Higher Education and Research/Franco-Thai Mobility Programme/PHC SIAM. Besides, the authors would like to thank Mr. Kijchai Kanjanapaparkul for his dedicated help in the batteries fabrication.

\section{SUPPLEMENTARY MATERIAL}

The Supplementary Material for this article can be found online at: https://www.frontiersin.org/articles/10.3389/fenrg. 2019.00015/full\#supplementary-material

Gavrilović-Wohlmuther, A., Laskos, A., Zelger, C., Gollas, B., and Whitehead, A. H. (2015). Effects of electrolyte concentration, temperature, flow velocity and current density on Zn deposit morphology. J. Energy Power Eng. 9, 1019-28. doi: 10.17265/1934-8975/2015.11.010

Hosseini, S., Lao-atiman, W., Han, S. J., Arpornwichanop, A., Yonezawa, T., and Kheawhom, S. (2018). Discharge performance of zinc-air flow batteries under the effects of sodium dodecyl sulfate and pluronic F-127. Sci. Rep. 8:14909. doi: 10.1038/s41598-018-32806-3

Ito, Y., Wei, X., Desai, D., Steingart, D., and Banerjee, S. (2012). An indicator of zinc morphology transition in flowing alkaline electrolyte. J. Power Sour. 211, 119-128. doi: 10.1016/j.jpowsour.2012.03.056

Jing, F., Paul, C. Z., Gyu, P. M., Aiping, Y., Michael, F., and Zhongwei, C. (2017). Electrically rechargeable zinc-air batteries: progress, challenges, and perspectives. Adv. Mater. 29:1604685. doi: 10.1002/adma.201604685

Lao-atiman, W., Julaphatachote, T., Boonmongkolras, P., and Kheawhom, S. (2017). Printed transparent thin film Zn-MnO2 battery. J. Electrochem. Soc. 164:A859-A863. doi: 10.1149/2.1511704jes

Lee, C. W., Sathiyanarayanan, K., Eom, S. W., Kim, H. S., and Yun, M. S. (2006). Effect of additives on the electrochemical behaviour of zinc anodes for zinc/air fuel cells. J. Power Sour. 160, 161-164. doi: 10.1016/j.jpowsour.2006.01.070

Li, Y., and Dai, H. (2014). Recent advances in zinc-air batteries. Chem. Soc. Rev. 43, 5257-5275. doi: 10.1039/C4CS00015C

Li, Y., Gong, M., Liang, Y., Feng, J., Kim, J.-E., Wang, H., et al. (2013). Advanced zinc-air batteries based on high-performance hybrid electrocatalysts. Nat. Comm. 4:1805. doi: 10.1038/ncomms2812

Mainar, A. R., Iruin, E., Colmenares, L. C., Kvasha, A., de Meatza, I., Bengoechea, M., et al. (2018). An overview of progress in electrolytes for secondary zinc-air batteries and other storage systems based on zinc. J. Energy Storage 15, 304-328. doi: 10.1016/j.est.2017.12.004

Mao, Z., and White, R. E. (1992). Mathematical modeling of a primary zinc/air battery. J. Electrochem. Soc. 139, 1105-1113. doi: 10.1149/1.2069348

Muralidharan, V. S., and Rajagopalan, K. S. (1978). Kinetics and mechanism of corrosion of zinc in sodium hydroxide solutions by steady-state and transient methods. J. Electroanalyt. Chem. Interfacial Electrochem. 94, 21-36. doi: 10.1016/S0022-0728(78)80395-7

Park, J., Park, M., Nam, G., Lee, J.-S., and Cho, J. (2015). All-solidstate cable-type flexible zinc-air battery. Adv. Mater. 27, 1396-1401. doi: 10.1002/adma.201404639 
Pei, P., Wang, K., and Ma, Z. (2014). Technologies for extending zinc-air battery's cyclelife: a review. Appl. Energy 128, 315-324. doi: 10.1016/j.apenergy.2014.04.095

Ravindran, V., and Muralidharan, V. S. (1995). Cathodic processes on zinc in alkaline zincate solutions. J. Power Sour. 55, 237-241. doi: 10.1016/0378-7753(95)02184-I

Saleh, M. M., Weidner, J. W., El-Anadouli, B. E., and Ateya, B. G. (1997). Electrowinning of nonnoble metals with simultaneous hydrogen evolution at flow-through porous electrodes: III. time effects. J. Electrochem. Soc. 144, 922-927. doi: 10.1149/1.1837508

Savaskan, G., Huh, T., and Evans, J. W. (1992). Further studies of a zinc-air cell employing a packed bed anode part I: discharge. J. Appl. Electrochem. 22, 909-915. doi: 10.1007/BF01024138

Schröder, D., and Krewer, U. (2014). Model based quantification of aircomposition impact on secondary zinc air batteries. Electrochim. Acta. 117, 541-553. doi: 10.1016/j.electacta.2013.11.116

Schröder, D., Laue, V., and Krewer, U. (2016). Numerical simulation of gasdiffusion-electrodes with moving gas-liquid interface: a study on pulsecurrent operation and electrode flooding. Comput. Chem. Eng. 84, 217-225. doi: 10.1016/j.compchemeng.2015.09.005

Sharifi, B., Mojtahedi, M., Goodarzi, M., and Vahdati Khaki, J. (2009). Effect of alkaline electrolysis conditions on current efficiency and morphology of zinc powder. Hydrometallurgy 99, 72-76. doi: 10.1016/j.hydromet.2009.07.003

Shivkumar, R., Paruthimal Kalaignan, G., and Vasudevan, T. (1995). Effect of additives on zinc electrodes in alkaline battery systems. J. Power Sour. 55, 53-62. doi: 10.1016/0378-7753(94)02170-8

Simičić, M. V., Popov, K. I., and Krstajić, N. V. (2000). An experimental study of zinc morphology in alkaline electrolyte at low direct and pulsating overpotentials. J. Electroanalyt. Chem. 484, 18-23. doi: 10.1016/S0022-0728(00)00035-8

Smedley, S. I., and Zhang, X. G. (2007). A regenerative zinc-air fuel cell. J. Power Sour. 165, 897-904. doi: 10.1016/j.jpowsour.2006.11.076

Sunu, W. G., and Bennion, D. N. (1980). Transient and failure analyses of the porous zinc electrode: i theoretical. J. Electrochem. Soc. 127, 2007-2016. doi: $10.1149 / 1.2130054$

Suren, S., and Kheawhom, S. (2016). Development of a high energy density flexible zinc-air battery. J. Electrochem. Soc. 163, A846-A850. doi: 10.1149/2.0361606jes
Wang, K., Pei, P., Ma, Z., Chen, H., Xu, H., Chen, D., et al. (2015a). Dendrite growth in the recharging process of zinc-air batteries. J. Mater. Chem. A 3 , 22648-22655. doi: 10.1039/C5TA06366C

Wang, K., Pei, P., Ma, Z., Chen, H., Xu, H., Chen, D., et al. (2015b). Growth of oxygen bubbles during recharge process in zinc-air battery. J. Power Sour. 296, 40-45. doi: 10.1016/j.jpowsour.2015.07.039

Wang, K., Pei, P., Wang, Y., Liao, C., Wang, W., and Huang, S. (2018). Advanced rechargeable zinc-air battery with parameter optimization. Appl. Energy 225, 848-856. doi: 10.1016/j.apenergy.2018. 05.071

Wang, Z., Meng, X., Wu, Z., and Mitra, S. (2017). Development of flexible zinc-air battery with nanocomposite electrodes and a novel separator. J. Energy Chem. 26, 129-138. doi: 10.1016/j.jechem.2016.08.007

Wongrujipairoj, K., Poolnapol, L., Arpornwichanop, A., Suren, S., and Kheawhom, S. (2017). Suppression of zinc anode corrosion for printed flexible zinc-air battery. Phys. Status Solidi B 254:1600442. doi: 10.1002/pssb.201600442

Xu, M., Ivey, D. G., Xie, Z., and Qu, W. (2015). Rechargeable Zn-air batteries: progress in electrolyte development and cell configuration advancement. $J$. Power Sour. 283, 358-371. doi: 10.1016/j.jpowsour.2015.02.114

Zhang, S. (2013). Status, opportunities, and challenges of electrochemical energy storage. Front. Energy Res. 1:8. doi: 10.3389/fenrg.2013.00008

Zhu, A. L., Wilkinson, D. P., Zhang, X., Xing, Y., Rozhin, A. G., and Kulinich, S. A. (2016). Zinc regeneration in rechargeable zinc-air fuel cells-a review. J. Energy Storage 8, 35-50. doi: 10.1016/j.est.2016.09.007

Conflict of Interest Statement: The authors declare that the research was conducted in the absence of any commercial or financial relationships that could be construed as a potential conflict of interest.

Copyright (C) 2019 Lao-atiman, Bumroongsil, Arpornwichanop, Bumroongsakulsawat, Olaru and Kheawhom. This is an open-access article distributed under the terms of the Creative Commons Attribution License (CC BY). The use, distribution or reproduction in other forums is permitted, provided the original author(s) and the copyright owner(s) are credited and that the original publication in this journal is cited, in accordance with accepted academic practice. No use, distribution or reproduction is permitted which does not comply with these terms. 


\section{NOMENCLATURE}

$a_{0}$ Initial solid-solution interface area per unit volume, $\mathrm{dm}^{2} / \mathrm{dm}^{3}$.

$a_{c}$ Specific surface area of catalyst per unit volume, $\mathrm{dm}^{2} / \mathrm{dm}^{3}$.

$a_{s}$ Solid-solution interface area per unit volume, $\mathrm{dm}^{2} / \mathrm{dm}^{3}$.

$A_{\text {zinc }}$ Active surface area of $\mathrm{Zn}$ electrode, $\mathrm{dm}^{2}$.

$A_{\text {air }}$ Active surface area of air electrode, $\mathrm{dm}^{2}$.

$A_{\text {sep }}$ Area of separator, $\mathrm{dm}^{2}$.

$C^{\text {ref }}$ Reference state concentration, $\mathrm{mol} / \mathrm{dm}^{3}$.

$C_{\mathrm{DL}}^{\text {zinc }}$ Double layer capacitance of $\mathrm{Zn}$ electrode, $\mathrm{F} / \mathrm{dm}^{2}$.

$C_{\mathrm{DL}}^{\text {air }}$ Double layer capacitance of air electrode, $\mathrm{F} / \mathrm{dm}^{2}$.

$C_{k}^{j}$ Concentration of specie $\mathrm{k}$ at electrode $j, \mathrm{~mol} / \mathrm{cm}^{3}$.

$D_{k}$ Diffusivity/diffusion coefficient of specie $k, \mathrm{dm}^{2} / \mathrm{s}$.

$E_{0, \text { cell }}$ NERNST potential/standard electrode potential, $\mathrm{V}$.

$E_{\text {cell }}$ Cell voltage, $\mathrm{V}$.

$E^{\text {zinc }}$ Reversible potential of $\mathrm{Zn}$ electrode, $\mathrm{V}$.

$E^{\text {air }}$ Reversible potential of air electrode, $\mathrm{V}$.

$E^{\mathrm{H}}$ Reversible potential of hydrogen evolution reaction, V.

F Faraday constant, $\mathrm{C} / \mathrm{mol}$.

$F_{\text {conv }}$ Convective volume flow, $\mathrm{dm}^{3} / \mathrm{s}$.

$F_{k, \text { in }}$ Inlet molar flowrate of specie $k, \mathrm{~mol} / \mathrm{s}$.

$F_{k \text {,out }}$ Outlet molar flowrate of specie $k$, mol/s.

I Electrical current, A.

$i^{\text {cell }}$ Current density, $\mathrm{A} / \mathrm{dm}^{2}$.

$i_{0}$ Exchange current density, $\mathrm{A} / \mathrm{dm}^{2}$.

$i_{0}^{\text {ref }}$ Reference exchange current density, $\mathrm{A} / \mathrm{dm}^{2}$.

$J_{k}$ Molar transfer rate between electrodes, $\mathrm{mol} / \mathrm{s}$.

$j_{k}^{\text {conv }}$ Convective molar flow rate, $\mathrm{mol} / \mathrm{s}$.

$j_{k}^{\text {diff }}$ Diffusion molar flow rate, $\mathrm{mol} / \mathrm{s}$.

$j_{k}^{m i g}$ Migration molar flow rate, $\mathrm{mol} / \mathrm{s}$.

$k_{s}$ Rate constant of $\mathrm{ZnO}$ precipitation reaction, $\mathrm{dm}^{3} / \mathrm{s}$.

$n_{e}$ Number of exchange electron involved in the reaction.

$N_{k}^{j}$ Moles of specie $k$ at electrode $j$, mol.

$P^{\text {ref }}$ Reference pressure, atm.
$P_{\mathrm{O}_{2}}$ Partial pressure of oxygen, atm.

$r_{i}$ Rate of reaction $i, \mathrm{~mol} / \mathrm{s}$.

$R$ Gas constant, $\mathrm{J} / \mathrm{mol} \cdot \mathrm{K}$.

$R_{\text {comp }}$ Resistivity of cell component, $\Omega \cdot \mathrm{dm}$.

$R_{\text {ohmic }}$ Total ohmic resistance, $\Omega$.

SV Space velocity, $\mathrm{s}^{-1}$.

$t$ Time, s.

$t_{k}$ Transference number of ion $k$.

$T$ Temperature, $\mathrm{K}$.

$V_{\text {electrolyte }}^{j}$ Volume of electrolyte at electrode $j, \mathrm{dm}^{3}$.

$V_{\text {solid }}^{\text {zinc }}$ Volume of solid Zn electrode, $\mathrm{dm}^{3}$.

$V_{\text {solid, } k}$ Volume of solid specie $k, \mathrm{dm}^{3}$.

$\bar{V}_{k}$ Specific molar volume of specie $k, \mathrm{dm}^{3} / \mathrm{mol}$.

$X_{\text {zinc }}$ Active surface fraction of $\mathrm{Zn}$ in solid phase.

$z_{k}^{ \pm}$Ion number of specie $k$

Greek symbol

$\alpha$ Charge transfer coefficient.

$\delta_{\text {air }}$ Thickness of air electrode, $\mathrm{dm}$.

$\delta_{\text {electrolyte }}$ Thickness of electrolyte, dm.

$\delta_{\text {zinc }}$ Thickness of $\mathrm{Zn}$ electrode, $\mathrm{dm}$.

$\delta_{\text {active }}$ Thickness of active reaction zone, $\mathrm{dm}$.

$\delta_{\text {sep }}$ Thickness of separator, $\mathrm{dm}$.

$\delta_{\mathrm{GDL}}$ Thickness of gas diffusion layer, $\mathrm{dm}$.

$\Delta E_{\mathrm{ZH}}$ Potential difference between $\mathrm{Zn}$ and hydrogen electrode, $\mathrm{V}$.

$\varepsilon$ Porosity of $\mathrm{Zn}$ electrode.

$\varepsilon_{0}$ Initial porosity of $\mathrm{Zn}$ electrode.

$\varepsilon_{\text {sep }}$ Porosity of separator.

$\eta_{\text {act }}^{\text {zinc }}$ Activation loss/activation overpotential of $\mathrm{Zn}$ electrode, $\mathrm{V}$.

$\eta_{\text {act }}^{\text {air }}$ Activation loss/activation overpotential of air electrode, $\mathrm{V}$.

$\eta_{\text {ionic }}^{\text {sep }}$ Ionic separator loss, $\mathrm{V}$.

$\eta_{\text {ohmic }}$ Ohmic loss/ohmic overpotential, V.

$\sigma_{\text {anode }}$ Total conductivity of anode, $\mathrm{S} / \mathrm{dm}$.

$\sigma_{\text {cathode }}$ Total conductivity of cathode, $\mathrm{S} / \mathrm{dm}$.

$\sigma_{k}$ Conductivity of specie $k, \mathrm{~S} / \mathrm{dm}$.

$\sigma_{\text {electrolyte }}$ Conductivity of electrolyte, S/dm.

$v_{k, i}$ Stoichiometric coefficient of specie $k$ in reaction $i$. 